\title{
Sea ice and pollution-modulated changes in Greenland ice core methanesulfonate and bromine
}

\author{
Olivia J. Maselli ${ }^{1, a}$, Nathan J. Chellman ${ }^{1}$, Mackenzie Grieman ${ }^{2}$, Lawrence Layman ${ }^{1}$, Joseph R. McConnell ${ }^{1}$, \\ Daniel Pasteris ${ }^{1}$, Rachael H. Rhodes ${ }^{3}$, Eric Saltzman ${ }^{2}$, and Michael Sigl ${ }^{1}$ \\ ${ }^{1}$ Department of Hydrologic Sciences, Desert Research Institute, Reno, NV, USA \\ ${ }^{2}$ Department of Earth System Science, University of California Irvine, Irvine, CA, USA \\ ${ }^{3}$ Department of Earth Sciences, University of Cambridge, Cambridge, UK \\ anow at: Department of Chemistry, University of Adelaide, Adelaide, Australia
}

Correspondence to: Olivia J. Maselli (olivia.maselli@gmail.com)

Received: 24 April 2016 - Published in Clim. Past Discuss.: 10 May 2016

Revised: 6 November 2016 - Accepted: 21 November 2016 - Published: 16 January 2017

\begin{abstract}
Reconstruction of past changes in Arctic sea ice extent may be critical for understanding its future evolution. Methanesulfonate (MSA) and bromine concentrations preserved in ice cores have both been proposed as indicators of past sea ice conditions. In this study, two ice cores from central and north-eastern Greenland were analysed at sub-annual resolution for MSA $\left(\mathrm{CH}_{3} \mathrm{SO}_{3} \mathrm{H}\right)$ and bromine, covering the time period 1750-2010. We examine correlations between ice core MSA and the HadISST1 ICE sea ice dataset and consult back trajectories to infer the likely source regions. A strong correlation between the low-frequency MSA and bromine records during pre-industrial times indicates that both chemical species are likely linked to processes occurring on or near sea ice in the same source regions. The positive correlation between ice core MSA and bromine persists until the mid-20th century, when the acidity of Greenland ice begins to increase markedly due to increased fossil fuel emissions. After that time, MSA levels decrease as a result of declining sea ice extent but bromine levels increase. We consider several possible explanations and ultimately suggest that increased acidity, specifically nitric acid, of snow on sea ice stimulates the release of reactive $\mathrm{Br}$ from sea ice, resulting in increased transport and deposition on the Greenland ice sheet.
\end{abstract}

\section{Introduction}

Atmospheric chemistry in the polar regions is strongly modulated by physical, chemical, and biological processes occurring in and around sea ice. These include sea salt aerosol generation, biogenic emissions of sulfur-containing gases and halogenated organics, and the photochemical-heterogeneous reactions leading to release of volatile, reactive bromine species. The resulting chemical signals influence the chemistry of the aerosol deposited on polar ice sheets. For this reason ice core measurements of sea salt ions, methanesulfonate (MSA), and bromine have been examined as potential tracers for sea ice extent (Abram et al., 2013; Spolaor et al., 2013b, 2016; Wolff et al., 2003). The interpretation of such tracers is complicated by the fact that their source functions reflect changes in highly complex systems, and signals are further modified by patterns of atmospheric transport and deposition.

MSA is produced by the atmospheric oxidation of dimethyl sulfide (DMS) $\left(\left(\mathrm{CH}_{3}\right)_{2} \mathrm{~S}\right)$. DMS is produced throughout the world's oceans as a breakdown product of the algal metabolite dimethylsulfoniopropionate (DMSP), $\left(\left(\mathrm{CH}_{3}\right)_{2} \mathrm{~S}^{+} \mathrm{CH}_{2} \mathrm{CH}_{2} \mathrm{COO}^{-}\right)$. DMS emissions are particularly strong in marginal sea ice zones (Sharma et al., 2012), and this source is believed to be a dominant contributor to the MSA signal in polar ice (Curran and Jones, 2000). Ice core MSA records have been used extensively in Antarctica as a proxy for local sea ice dynamics. Although the specifics of the relationship are highly site-dependent (Abram et al., 2013; Curran et al., 2003), MSA has been proven to be a rea- 
sonably good proxy for sea ice conditions (e.g. Curran and Jones, 2000). In the Arctic, the relationship between MSA and sea ice conditions is less straightforward due to the likelihood of multiple source regions with different sea ice conditions contributing to the ice core archived MSA (Abram et al., 2013). Until now, a significant $(r=-0.66)$ relationship between ice core MSA and Arctic sea ice extent (specifically August in the Barents sea) has only been established for a short record from a Svalbard ice core (O'Dwyer et al., 2000). In this study we analyse the direct correlations between the MSA records from two Greenland ice core sites and the surrounding sea ice conditions in order to demonstrate the utility of MSA as a local sea ice proxy.

In this study, all dissolved or suspended bromine species are measured (including organic bromine) and shall be referred to as "bromine". The primary source of total inorganic bromine (e.g. $\mathrm{Br}_{2}, \mathrm{Br}^{-}, \mathrm{HBr}$ ) in the marine boundary layer (MBL) is the ocean (Parrella et al., 2012; Sander et al., 2003). At concentrations of less than $0.2 \%$ that of sodium $(\mathrm{Na})$, bromide $\left(\mathrm{Br}^{-}\right)$makes a small contribution to ocean salinity. $\mathrm{Br}^{-}$can be concentrated in the high-latitude oceans when the sea water is frozen, since the formation of the ice matrix exudes the sea salts in the form of brine (Abbatt et al., 2012). Small sea-salt aerosol particles blown from the surface of sea ice are typically enriched with bromine (Sander et al., 2003) and satellite imagery has revealed that plumes of bromine (as $\mathrm{BrO}$ ) are photochemically released from sea ice zones in spring (Nghiem et al., 2012; Schönhardt et al., 2012; Wagner et al., 2001). Recently, studies have begun to link ice core records of bromide enrichment (relative to sea water $\mathrm{Na}$ concentrations) preserved in polar ice sheets to that of local sea ice conditions (Spolaor et al., 2013a, b, 2014). Spolaor and co-workers demonstrated the springtime $\mathrm{Br}^{-} / \mathrm{Na}$ that is preserved in the ice core is a record of bromine explosion events over adjacent seasonal sea ice. $\mathrm{A} \mathrm{Br}^{-}$/ Na enrichment would therefore indicate a larger seasonal sea ice extent or conversely a shorter distance between the ice edge and the ice core site due to decreased multi-year sea ice (Spolaor et al., 2013a). However, like MSA, it is likely that the bromine-sea ice relationship in the Arctic is complicated by the myriad of bromine source regions which influence an ice core record in addition to factors which influence the degree of enrichment of the aerosol as it travels to the ice core site. In this study we compare ice core records of bromine to those of MSA and other common MBL species in order to determine the influence of sea ice conditions and other factors on bromine concentrations.

Here, we present measurements of MSA, bromine, and elemental tracers of sea salt and crustal input in two Greenland ice cores covering the time period 1750-2010 CE. These ice core records represent the first continuous sub-annual resolution records of bromine in polar ice to extend beyond the satellite era. We examine the relationship between these two sea ice-modulated tracers, their relationship to independent

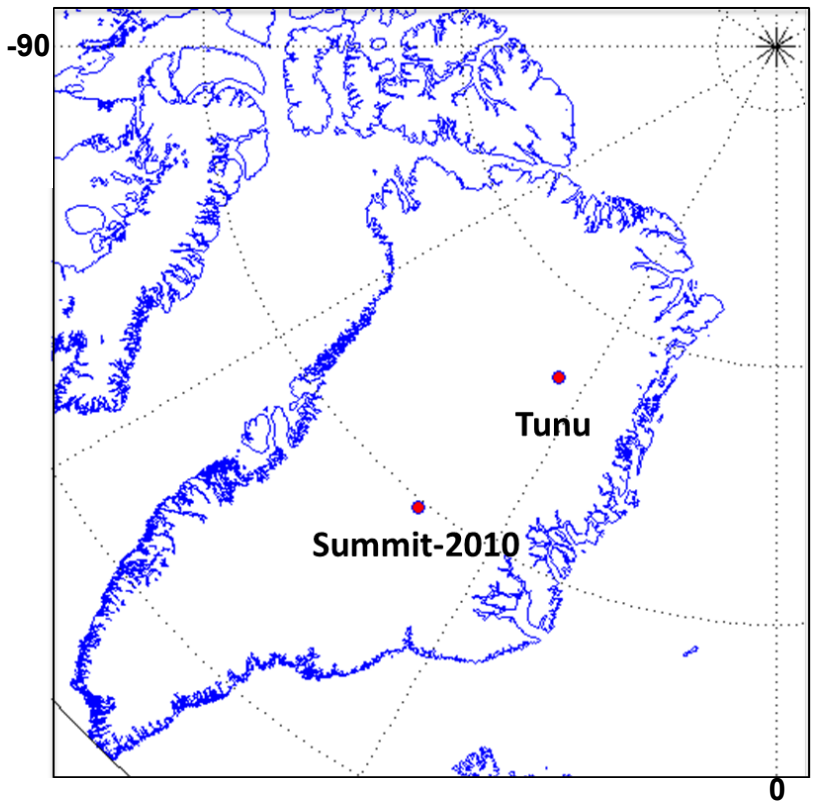

Figure 1. Locations of ice cores used in this study. Summit-2010 $\left(72^{\circ} 20^{\prime} \mathrm{N}, 38^{\circ} 17^{\prime} 24^{\prime \prime} \mathrm{W}\right)$ and Tunu $\left(78^{\circ} 2^{\prime} 5.5^{\prime \prime} \mathrm{N}, 33^{\circ} 52^{\prime} 48^{\prime \prime}\right)$.

historical estimates of sea ice distribution, and the influence of industrialization on atmospheric and ice core chemistry.

\section{Methods}

\subsection{Ice cores}

The $87 \mathrm{~m}$ "Summit-2010" ice core was collected in 2010 close to Summit Station, Greenland ( $72^{\circ} 20^{\prime}$ N $38^{\circ} 17^{\prime} 24^{\prime \prime}$ W; Fig. 1). The average snow accumulation at Summit, as determined from the ice core record, is $\sim 0.22 \mathrm{~m} \mathrm{year}^{-1}$ water equivalent, with few instances of melt. Due to the relatively high snow accumulation rate, seasonal analysis of the sea salt species concentrations was feasible. The $213 \mathrm{~m}$ Tunu core was collected in $2013\left(78^{\circ} 2^{\prime} 5.5^{\prime \prime} \mathrm{N}, 33^{\circ} 52^{\prime} 48^{\prime \prime} \mathrm{W}\right.$, Fig. 1), approximately $3 \mathrm{~km}$ east of the Tunu-N automatic weather station, part of the Greenland Climate Network. The average snow accumulation at Tunu, as determined from the ice core record, is $\sim 0.11 \mathrm{~m} \mathrm{year}^{-1}$ water equivalent.

The Summit-2010 and Tunu cores were first dated using volcanic horizons in sulfur (S) from well-dated historic eruptions (e.g. 1815, 1835, 1846, 1854, 1873, 1883, 1912). To aid the volcanic horizon assignment in the Tunu core the non-sea-salt $\mathrm{S}$ record was synchronized to the NEEM2011-S1 volcanic record (Sigl et al., 2015). The dating of both cores was then refined by annual layer counting using a combination of seasonal cycles in $\mathrm{Na}, \mathrm{Ca}$, and the ratio of non-sea-salt $\mathrm{S} / \mathrm{Na}$ for each entire core. In addition, hydrogen peroxide was used as a winter marker in the upper section of the Summit-2010 core. January was defined as the minimum value in the ratio of non-sea-salt $\mathrm{S} / \mathrm{Na}$. 
Bigler et al. (2002) demonstrated that the input of anthropogenic sulfate during the Arctic haze slightly shifted the seasonal cycle of sulfate preserved in a north-eastern Greenland ice core ice toward spring by, on average, 1 month. The ratio of the $\mathrm{Na}$ to $\mathrm{S}$ was thus used to define the formal annual layer boundaries because using the ratio of two tracers with opposing seasonality (winter $\mathrm{Na}$ maximum and summer S maximum) reduces the sensitivity of the series to any small temporal fluctuations. Comparison with weekly surface snow samples collected from Summit (from 2007-2013; GEOSummit project) confirms the assignment of a non-seasalt S / Na minimum in December/January. Monthly values were calculated assuming a constant distribution of snowfall within each year. Due to the lower accumulation rate and strong katabatic winds at the Tunu site, constraints from volcanic synchronization played a more important role in developing the depth-age scale for the Tunu core compared with Summit-2010. This dating technique is described in more detail for another Greenland ice core (NEEM-2011-S1) by Sigl et al. (2013, 2015). The annual layer dating for these ice cores resulted in a plutonium record that is consistent with other ice cores from Greenland between 1950 and 1970 and with the emission histories from nuclear weapon testing in the Northern Hemisphere (Arienzo et al., 2016). The error in the dating of the ice core records was estimated as \pm 0.33 years for the Summit-2010 record and \pm 1 year for the Tunu record.

\subsection{Sampling and analysis}

The ice cores were sampled from $33 \times 33 \mathrm{~mm}$ cross-section sticks using a continuous melter system (McConnell et al., 2002). The silicon carbide melter plate provides three streams from concentric square regions of the ice core sample: an innermost stream (with a cross sectional area of $\left.144 \mathrm{~mm}^{2}\right)$, an intermediate stream $\left(340 \mathrm{~mm}^{2}\right)$, and an outer stream that was discarded along with any contaminants obtained from handling of the ice core. The innermost melt stream was directed to two inductively coupled plasma-mass spectrometers (ICP-MS, Thermo Scientific Element 2 highresolution with PFA-ST concentric Teflon nebulizer (electrospray ionization - ESI)) run in parallel. All calibrations and runtime standards were run on both instruments and several elements were also measured in duplicate $(\mathrm{Na}, \mathrm{Ce}, \mathrm{Pb})$ to ensure tracking between both ICP-MSs. In addition, an internal standard of yttrium flowed through the entire analytical system and was used to observe any change in system sensitivity. The instrument measuring bromine was run at medium resolution and there were no mass interferences observed at the bromine isotope mass monitored ( $79 \mathrm{amu})$. The sample stream was acidified to $1 \% \mathrm{HNO}_{3}$ to prevent loss of less soluble species, degassed just prior to analysis to minimize mixing in the sample line and sampled at a rate of $0.45 \mathrm{~mL} \mathrm{~min}^{-1}$ (McConnell et al., 2002; Sigl et al., 2013). The following elements were measured by ICP-MS: $\mathrm{Br}, \mathrm{Cl}, \mathrm{Na}, \mathrm{Ca}, \mathrm{S}, \mathrm{Ce}$, and $\mathrm{Pb}$. Calibration of the ICP-MS was based on a series of seven mixed standards measured at the start and end of each day for all elements except for the halides. Due to the high volatility of acid halides, a set of four bromine and chlorine standards were made individually in a $1 \%$ ultra high purity $\mathrm{HNO}_{3}$ matrix from fresh, non-acidified intermediate stock solution (Inorganic Ventures) every day. The intermediate melt stream was directed to a continuous flow analysis (CFA) system on which nitrate ion $\left(\mathrm{NO}_{3}^{-}\right)$and snow acidity (sum of soluble acidic species) were measured using the technique described by Pasteris et al. (2012) in addition to other atmospheric species of interest (Röthlisberger et al., 2000). Stable water isotope records were also collected using the CFA system according to the method described by Maselli et al. (2013).

The analysis of MSA by batch analysis using electrospray triple-quad mass spectrometer (ESI-MS-MS) has been reported previously (Saltzman et al., 2006). A portion of the debubbled CFA melt stream $\left(150 \mu \mathrm{L} \mathrm{min}^{-1}\right)$ was subsampled for continuous online analysis of methanesulfonate by ESI-MS-MS (Thermo-Finnigan Quantum). This subsample was mixed with pure methanol $\left(50 \mu \mathrm{L} \mathrm{min}^{-1}\right)$ delivered using an M6 pump (syringe-free liquid handling pump, Valco Instruments Company Inc.). The methanol was spiked with an internal standard of deuterated MSA $\left(\mathrm{CD}_{3} \mathrm{SO}_{3}^{-}\right.$; Cambridge Isotopes) at a concentration of $52 \mathrm{nM}$. The internal isotope standard was used to correct for any changes in instrument response due to variations in water chemistry (such as acidity). The isotope standard was calibrated against non-deuterated MSA standards prepared in water from nondeuterated MSA $\left(\mathrm{CH}_{3} \mathrm{SO}_{3}^{-}\right.$; Sigma Aldrich). MSA was detected in negative ion mode using the $\mathrm{CH}_{3} \mathrm{SO}_{3}^{-} / \mathrm{SO}_{3}^{-}$transition $(m / z 95 / 80)$ and $\mathrm{CD}_{3} \mathrm{SO}_{3}^{-} / \mathrm{SO}_{3}^{-}(m / z 98 / 80)$. The concentration of MSA in the sample flow was determined from the ratio of the non-deuterated and deuterated signals after minor blank corrections. This study is the first use of the technique for ice core MSA analysis in a continuous online mode. The uncertainty in the MSA intensity as calculated from the standard calibrations is $1 \%$.

A second portion of the debubbled CFA melt stream was directed to an autosampler collection system to collect a discretely sampled archive of the melted ice cores. The collected samples were frozen at the end of each day and later analysed for MSA again using ion chromatography and ESI-MS-MS.

\subsection{Calculation of anthropogenic $\mathrm{Pb}$, non-sea-salt $\mathrm{S}$, and $\mathrm{Br}$ enrichment}

The $\mathrm{Pb}$ derived from anthropogenic sources $(\mathrm{exPb})$ was calculated as the difference between total lead measure in the ice core, $[\mathrm{Pb}]_{\mathrm{obs}}$, and that from dust sources. The $\mathrm{Pb}$ from dust was calculated as a fraction of the dust proxy cerium, ([Ce $\left.]_{\text {obs }}\right)$ as follows:

$\operatorname{exPb}=[\mathrm{Pb}]_{\text {obs }}-[\mathrm{Ce}]_{\mathrm{obs}} \times\left(\frac{[\mathrm{Pb}]}{[\mathrm{Ce}]}\right)_{\text {dust }}$, 
where the relative amount of $\mathrm{Pb}$ in dust, $([\mathrm{Pb}] /[\mathrm{Ce}])_{\text {dust }}$, has the constant mass ratio of 0.20588 (Bowen, 1979).

Similarly the amount of non-sea-salt sulfur (nssS) was calculated relative to the sea salt sodium ( $\mathrm{ssNa})$ :

$\mathrm{nssS}=[\mathrm{S}]_{\mathrm{obs}}-[\mathrm{ssNa}] \times\left(\frac{\left[\mathrm{SO}_{4}^{2-}\right]}{[\mathrm{Na}]}\right)_{\text {seawater }}$,

where the amount of sulfur relative to $\mathrm{Na}$ in sea water, $\left(\left[\mathrm{SO}_{4}^{2-}\right] /[\mathrm{Na}]\right)_{\text {seawater }}$ has the constant mass ratio of 0.252 (Millero, 1974). The ssNa was calculated by comparison with calcium as both have sea salt and dust origins (Röthlisberger et al., 2002):

$\operatorname{ssNa}=\frac{\left[\mathrm{Na}_{\mathrm{obs}} \times R_{\mathrm{t}}-\mathrm{Ca}_{\mathrm{obs}}\right]}{\left[R_{\mathrm{t}}-R_{\mathrm{m}}\right]}$,

where $R_{\mathrm{t}}$ and $R_{\mathrm{m}}$ are the $\mathrm{Ca} / \mathrm{Na}$ mean crustal and mean marine mass ratios of 1.78 and 0.038 , respectively (Millero, 1974).

Bromine enrichment factors relative to sea water concentrations were calculated using the following:

$\operatorname{enrBr}(\mathrm{Na})=\left(\frac{[\mathrm{Br}]}{[\mathrm{Na}]}\right)_{\text {obs }} /\left(\frac{[\mathrm{Br}]}{[\mathrm{Na}]}\right)_{\text {seawater }}$,

where the $([\mathrm{Br}] /[\mathrm{Na}])_{\text {seawater }}$ mass ratio is 0.00623 (Millero, 1974).

\subsection{Air mass back trajectories}

To identify the likely sea ice source regions of MSA and $\mathrm{Br}$ deposited at the ice core sites, we perform 10-day air mass back trajectories of boundary layer air masses from each ice core site using the GDAS1 archive dataset in the Hysplit4 software (Draxler and Hess, 1998). The starting height of the back trajectories was $500 \mathrm{~m}$ to ensure that the monitored air masses travelled close enough to the surface at the ice core site to potentially deposit aerosols. The vertical velocity field was taken from the meteorological data files. Air mass back trajectories were started every $12 \mathrm{~h}$ and allowed to travel for 10 days (total number of trajectories hours $=14400 \mathrm{~h}$ per month). The number of hours that the trajectories spent in a $2^{\circ} \times 2^{\circ}$ grid was summed over all of the trajectories for that month between the years 2005 and 2013. Previous work showed that the rapid advection of MBL air was the likely source of reactive halogens at Summit (Sjostedt et al., 2007).

\subsection{Sea ice correlation mapping}

In order to assess the relationships between sea ice conditions and ice core chemistry, correlation maps were generated between annual MSA concentrations and monthly sea ice using the HadISST1 ICE dataset at $1^{\circ}$ latitude-longitude monthly resolution (Rayner, 2003). Pre-1979 sea ice datasets were interpolated from sea ice extent maps compiled by
Walsh (1978) which incorporate a variety of empirical observations. The data were later bias-corrected using modern satellite data (Rayner, 2003). Correlations were performed separately for the satellite period (1979-2012) and for the extended record (1900-2012), excluding the period 19401952 when the record has no variability due to scarcity of data (Rayner, 2003). Because strong DMS emissions occur in marginal sea ice zones (Sharma et al., 2012), we considered both sea ice concentration (SIC) and the area of open water in the sea ice pack (OWIP) which represents the size of the marginal sea ice zone. OWIP is defined as the difference between sea ice area (calculated from sea ice concentration over the area of the grid cell) and sea ice extent (NSIDC). A SIC of $15 \%$ was used as the threshold for a grid cell to contribute to sea ice extent. The area of OWIP was calculated within the coastal areas as defined by the results of the air mass back trajectories (Sect. 3.4).

Outliers were removed from the MSA time series (see Fig. 2) before the correlations were performed. The outliers were removed using the technique described by Sigl et al. (2013) for identifying volcanic signals using a 25-year running average filter. Correlations were performed on an annual rather than seasonal basis because the seasonality of ice core MSA is distorted due to post-depositional migration of MSA signal at depth in the snowpack (Mulvaney et al., 1992) (Fig. 3 in the article and Fig. S1 in the Supplement).

\section{Results}

\subsection{Bromine}

Ice core measurements of bromine at Summit and Tunu covering the period 1750-2010 are shown in Fig. 2. Ice core $\mathrm{Br}$ levels at each site were stable until $\sim 1820$ at Summit and $\sim 1840$ at Tunu when they both decreased by $\sim 1 \mathrm{nM}$, establishing a new baseline that was stable until the mid-1900s. Both ice cores also show a Br peak in the late 20th century. The concentration values and the timing of inflections in concentrations were determined by a three-step linear regression of the dataset. The analysis was performed by simultaneous linear least squares fitting of three straight lines joined by "inflection points" to the dataset. The variables of the fitting procedure were the slopes and intercepts of each line as well as the $x$ axis locations at which the total function switched from one linear section to the next (the inflection points). Initial guess values were supplied for each variable to help the fitting procedure reach reasonable values. A summary of the regression results can be found in Table S1 in the Supplement.

Sea salt transport onto the Greenland ice sheet occurs predominantly during winter. Historically the wintertime sea salt maximum was believed to be due to increased cyclonic activity over the open oceans (Fischer and Wagenbach, 1996) though more contemporary studies show that blowing snow from the surface of sea ice may be a significant source 

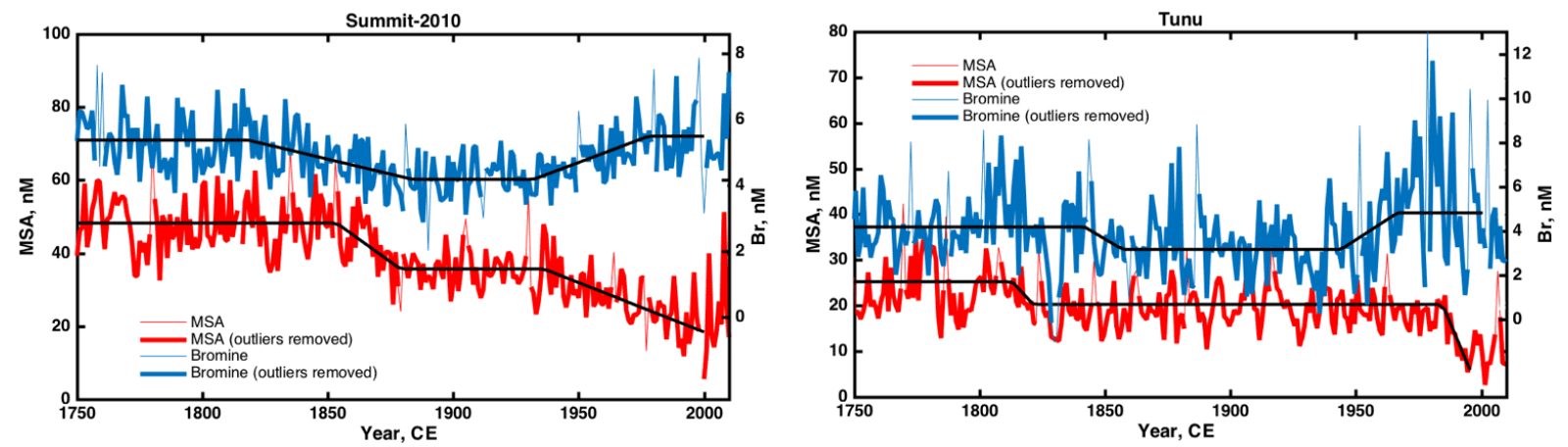

Figure 2. Annual record of bromine (thin blue) and MSA (thin red). Annual record of bromine (thick blue) and MSA (thick red) with outlying spikes removed using a 25-year running average filter described by Sigl et al. (2013). All records were fit with a three-step linear regression (black) and the results of the fits which identify the timing of inflection points are summarized in Table $S 1$. The time series have been plotted to match the signal variability in the pre-industrial era (1750-1850 CE).

(Rankin et al., 2002; Xu et al., 2013; Yang et al., 2008, 2010). At Summit, a wintertime maximum is observed in the most abundant sea salts, $\mathrm{Na}$ and $\mathrm{Cl}$ (Fig. 3). Bromine also shows a significant wintertime signal, however the annual maximum appears in midsummer - at concentrations $\sim 70 \%$ above winter levels (Fig. 3a). Comparison with $\mathrm{Br}$ measured in weekly surface snow samples collected from Summit (from 2007 to 2013; GEOSummit project) confirms that this summer signal is real and not a result of post-depositional modification of seasonality of the bromine signal (Fig. S2). The results from that study confirm that total $\mathrm{Br}$ concentrations peak in summer on the ice sheet closely following the Br cycle observed in the Summit-2010 ice core. In addition to the comparison with the GEOSummit data, in the ice cores studied here there are routinely more than 10 measurements made within a yearly layer of snow, giving confidence to the allocation of a summer maximum in bromine at Summit. Analysis of the annual cycle of bromine in the Tunu ice core also shows a summer maximum when averaged over the entire ice core time series but with significantly larger error than observed at Summit. The timing of this peak suggests a predominant summertime deposition of bromine that dwarfs that from winter sea salt sources.

The shape of the annual bromine cycle does change slightly over the course of the Summit record (see Fig. 3). Starting in the early 1900s, the annual bromine cycle slowly becomes broader. A slight shift in the maximum from a solely summer peak in the pre-industrial era towards a broad spring-summer peak by 1970 is observed (Fig. 3 lower panel). Comparison with the sea salt tracer, sodium, which does not undergo the large temporal shift and broadening of its seasonal cycle shows that this change in bromine seasonality is not linked to changes in production or transport of sea salt aerosols or even dating uncertainties in the ice core but perhaps the introduction of an additional, smaller bromine source in the springtime during the industrial era.
Both ice cores show a predominantly positive $\mathrm{Br}$ enrichment throughout the year (Figs. S3, S4) relative to both sea salt elements chlorine and sodium. This enrichment reaches a maximum in mid-to-late summer at Summit (Fig. 3). We assume that this enrichment reflects $\mathrm{Br}$ enrichment in the aerosol transporting $\mathrm{Br}$ to the ice sheet. In a comprehensive review of global aerosol $\mathrm{Br}$ measurements, Sander et al. (2003) concluded that in general, aerosols which showed positive $\mathrm{Br}$ enrichment factors were of sub-micrometre size. These small aerosols can travel further (lifetimes of around 5-10 days) and due to their larger surface / volume ratio may experience more atmospheric processing than larger aerosols, resulting in the positive enrichment. However, postdepositional reduction of the bromine concentration is a possibility during the summer months due to photolytic processes at the snow surface. This may be the cause of the noisiness of the bromine signal within the lower accumulation Tunu core. However, the increased snow accumulation that occurs during the summer months in both central and northern Greenland (Chen et al., 1997) should act to minimize these bromine-depleting effects driven by increased insolation in summer, and indeed Weller (2004) has shown that accumulation rates of this size are large enough to prevent the post-deposition loss of other species such as nitrate and MSA.

Both sites also show a (small) positive enrichment of chlorine relative to sodium, which is amplified at small sodium concentrations. Chlorine-containing aerosols are expected to undergo similar chemical processing to bromine-containing aerosols but the enrichment factors of bromine (relative to sodium) are much larger, which is likely due to the high solubility of bromine species such as $\mathrm{HBr}$ (Sander et al., 2003). Alternatively, the chlorine enrichment could be interpreted as a sodium depletion of the aerosols particularly in those of small diameter where both concentrations are low; this would amplify the bromine enrichment (relative to sodium) but would not explain the bromine enrichment relative to 


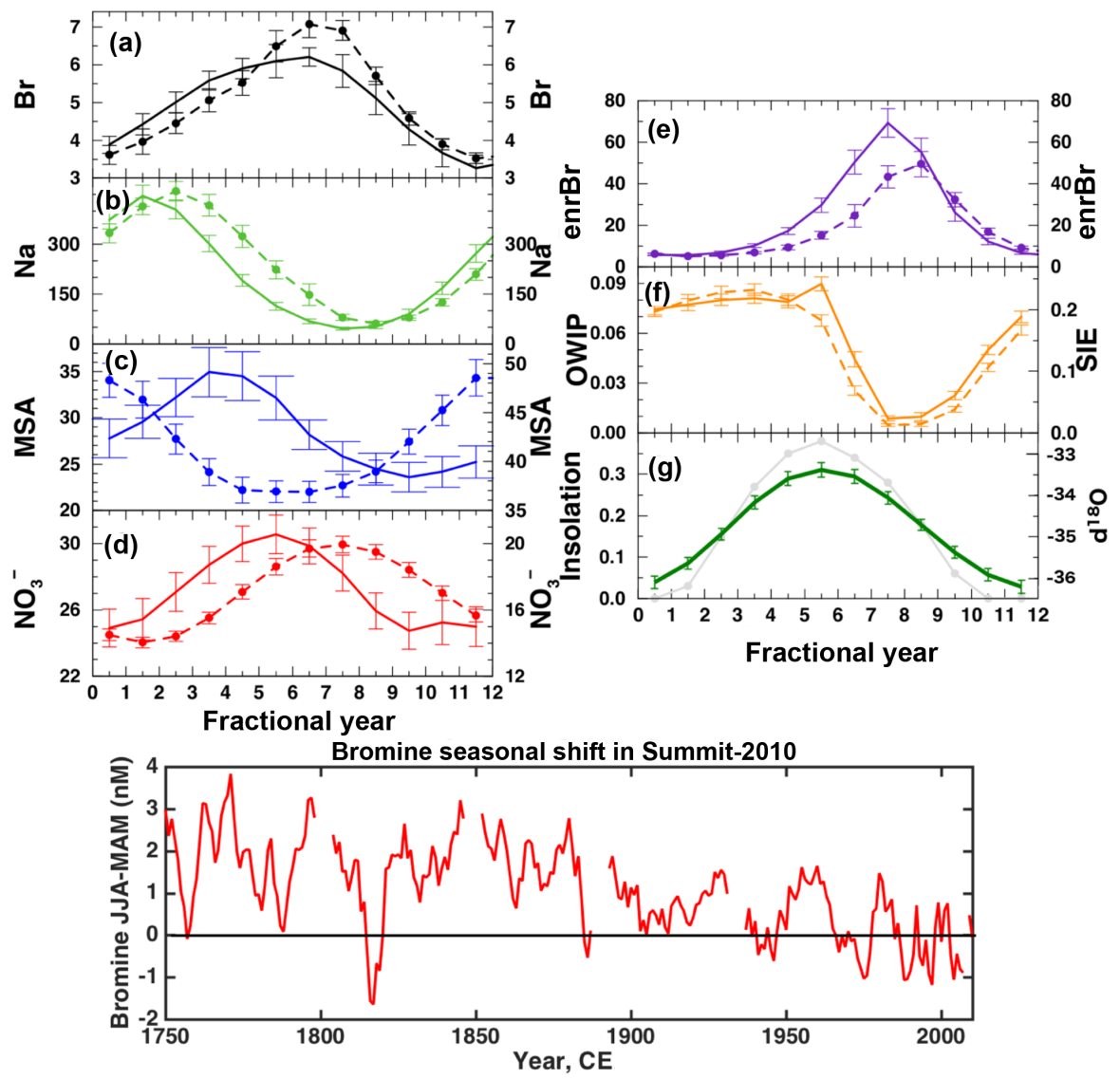

Figure 3. Upper panels: average seasonal cycle of species in the Summit-2010 ice core. The left-hand $y$ axes are associated with the solid lines and the right-hand $y$ axes associated with the dashed lines. Dashed lines (a-e) average seasonal cycle from depths $43.5-87.3 \mathrm{~m}$ (years 1742-1900). Solid lines (a-e) average seasonal cycle from 0 to $43.5 \mathrm{~m}$ (years 1900-2010). Error bars indicate the standard error of the monthly value. (a) Total bromine, (b) total sodium, (c) MSA, and (d) nitrate. Units for (a-d) are nM. Note that the seasonal cycle in bromine appears to broaden in the 1900-2010 period (see lower panel). Note also that the MSA maximum shifts from spring in the shallowest part of the ice core (solid line) to winter in the deepest part of the ice core (dashed line) due to post-depositional effects (see Fig. S1). (e) Average seasonal cycle in bromine enrichment (relative to sea salt sodium; see Eq. 3). (f, right) The sea ice extent (SIE $\left.\times 10^{6} \mathrm{~km}{ }^{2}\right)$ within an area of the East Greenland coast $\left(70-63^{\circ} \mathrm{N}, 15-45^{\circ} \mathrm{W}\right)$. (f, left) Area of open water within the sea ice pack $\left(\mathrm{OWIP} \times 10^{6} \mathrm{~km}{ }^{2}\right)$ for the area defined by SIE. (g, left) Solar insolation at 12:00 GMT at the latitude of Summit (http://eosweb.larc.nasa.gov). (g, right) Annual cycle of the $\delta^{18} \mathrm{O}$ water signal averaged over 1900-2010 CE. Lower panel: broadening of bromine seasonal cycle in the Summit-2010 ice core. The difference between the summer and spring bromine signal (JJA-MAM) was monitored over the length of the entire ice core. In the pre-industrial era (pre-1850) bromine peaks in summer; realised as positive values of JJA-MAM. After 1900 there is a marked broadening of the seasonal signal towards spring and by $\sim 1970$ the seasonal signal maximum is routinely shared between summer and spring realised as an averaged JJA-MAM of approximately zero.

chlorine. It is likely that both halogens undergo some degree of enrichment and the sodium undergoes some depletion in the aerosols though it is difficult to determine this from the data.

A summertime maximum in Br enrichment was also observed by Spolaor et al. (2014) in short segments of Antarctic Law Dome ice core as well as two Arctic ice cores. Spolaor et al. believe that the main source of the inorganic bromine originated from springtime bromine explosion events above sea ice and the summertime maximum could possibly be an indication of lag time between bromine-containing particles becoming airborne and their deposition. Further investigation is needed to definitively establish the seasonality of bromine deposition at the poles. However, the results of the Arctic ice cores studied here suggest that the summer maximum in bromine deposition is indeed real.

In the Tunu ice core, $11 \%$ of the monthly bromine enrichment measurements relative to $\mathrm{Na}$ were negative (less than the $\mathrm{Br} / \mathrm{Na}$ seawater ratio, Fig. S3) and $12 \%$ were negative relative to $\mathrm{Cl}$. It is possible that the negative enrichment values observed in the Tunu ice core are therefore a result of larger aerosols ( $>$ micrometre) reaching the site due to its 
proximity to the coast (and thus the likely sea ice aerosol source region) in comparison to Summit.

\subsection{MSA}

The Summit-2010 MSA record (Fig. 2) replicates that measured by Legrand in 1993 (Legrand et al., 1997) and extends it an additional 17 years (see Fig. S5). The mean Summit-2010 MSA measurements over the period 1984$1992(2.0 \pm 0.7(1 \sigma) \mathrm{ppb})$ also compare well with the results of the sub-annually sampled Summit snow pit study performed by Jaffrezo et al. (1994); $2.1 \pm 1.8(1 \sigma) \mathrm{ppb}$. Both the Legrand and Jaffrezo studies measured MSA using ion chromatography of discretely sampled snow and ice. The similarity between the Summit-2010 measurements and the results of these studies demonstrates that the new, continuous technique is able to achieve a comparable accuracy in MSA measured concentrations to the traditional, discrete technique. It also demonstrates that negligible amounts of MSA are being lost by using the continuous melt method.

The Tunu measurements represent the first MSA profile at this location. Replicate measurements of the entire Tunu ice core were performed with the online, continuous technique by melting a secondary stick of ice cut from the original Tunu ice core. The replicate measurements closely followed the original MSA measurements demonstrating the reproducibility, stability, and high precision of the continuous MSA technique (Fig. S6). The Tunu MSA record was also reproduced using discrete samples collected from the CFA system (Fig. S7).

At Summit, MSA concentrations averaged $48 \mathrm{nM}$ in the late 18th century, compared with just $27 \mathrm{nM}$ at Tunu. From 1878 to 1930 MSA concentrations at Summit plateaued at $36 \mathrm{nM}$ after which they began to drop rapidly, at a rate of $0.27 \mathrm{nM}$ year $^{-1}$, reaching $18 \mathrm{nM}$ by $2000 \mathrm{CE}$. Large fluctuations in the MSA record after this time make it difficult to assess the most recent trend in Summit MSA concentrations. MSA concentrations in the Tunu core showed a similar temporal variability to those in the Summit record, and until the mid-20th century, were consistently lower in magnitude. MSA concentrations only began to decline consistently at Tunu after 1984, almost 50 years after the rapid decline observed in the Summit record. After 2000 CE, large fluctuations in concentration were again observed, making the modern-day trend in MSA concentration at Tunu difficult to establish.

Comparison with the total sulfur record (Fig. 4) reveals that during the pre-industrial period, MSA contributes to $\sim 12$ and $\sim 7 \%$ of the total sulfur signal at Summit and Tunu, respectively, compared with $<2 \%$ at the height of the industrial period (1970 CE) at both sites.

The low-frequency, pre-industrial trend in MSA concentrations seen in these ice core records closely follows that of bromine; particularly distinct is the decrease in both MSA and bromine at both sites in the early to mid-1800s (Tables S1 and S2). In the 1900s, however, both sites show a divergence between the MSA and Br records - as MSA begins to decline, $\mathrm{Br}$ concentrations increase.

A dramatic shift in the "timing" of the annual MSA maximum in the Summit-2010 ice core is illustrated in Figs. 3c and S1. The signal shifts gradually and continuously along the length of the entire Summit-2010 record from a spring to winter maximum (Fig. S1). This phenomenon has previously been observed in several Antarctic ice cores and has been attributed to post-depositional migration within the ice due to salt gradients (Mulvaney et al., 1992; Weller, 2004). At very low-accumulation ice core sites, post-depositional loss of MSA (and nitrate) must also be considered. Extrapolation of data collected by Weller (2004) from a series of East Antarctic ice cores predicts that sites with annual average accumulations of greater than $105 \mathrm{~kg} \mathrm{~m}^{-1}$ year $^{-1}\left(0.105 \mathrm{~m} \mathrm{year}^{-1}\right)$ will not show post-depositional loss of MSA (or nitrate). Both ice cores in this study have sufficient average annual accumulation that post-depositional loss of MSA (and nitrate) is predicted to be negligible and so is not discussed further.

\subsection{Acidic species}

In winter, with the collapse of the polar vortex, polluted air masses enter the Arctic region as the phenomenon known as the Arctic haze (Barrie et al., 1981; Li and Barrie, 1993). $\mathrm{SO}_{2}$ and $\mathrm{NO}_{x}$ from the haze are adsorbed onto aerosols or deposited directly on the ice/snow and oxidised to sulfuric $\left(\mathrm{H}_{2} \mathrm{SO}_{4}\right)$ and nitric acid $\left(\mathrm{HNO}_{3}\right)$. There are also natural sources of $\mathrm{SO}_{2}$ (biomass burning, volcanic eruptions, oceans - Li and Barrie, 1993; McConnell et al., 2007; Sigl et al., 2013) and $\mathrm{NO}_{x}$ (microbial activity in soils, biomass burning, lightning discharges - Vestreng et al., 2009) as well as other snow/ice acidifiers including MSA, hydrogen chloride, and organic acids released from biogenic or biomass-burning sources (Pasteris et al., 2012).

The annual cycle for nitrate $\left(\mathrm{NO}_{3}^{-}\right)$is shown in Fig. 3d. Before $1900 \mathrm{CE}$ the nitrate shows a seasonal maximum in late summer/early autumn after which the maximum shifts to late spring/early summer. Although there are biological sources of $\mathrm{NO}_{3}^{-}$in the ice core aerosol source regions, in a recent study focused on the $\mathrm{NO}_{3}^{-}$and $\delta^{15} \mathrm{~N}-\mathrm{NO}_{3}^{-}$record in the Summit-2010 ice core, Chellman et al. (2016) concluded that the pre-industrial (1790-1812 CE) $\mathrm{NO}_{3}^{-}$seasonal cycle was driven by biomass-burning emissions. However, in the modern era (1930-2002 CE) oil-burning emissions became the dominant source of $\mathrm{NO}_{3}^{-}$in the snowpack. The change in the dominant $\mathrm{NO}_{3}^{-}$source due to industrialization is the cause of the shift in timing of the seasonal cycle.

Total snow acidity was stable at both sites from 1750 through to $\sim 1900 \mathrm{CE}$, except for sporadic, short-lived spikes due to volcanic eruptions. The average pre-industrial acidity was the same at both sites $(\sim 1.8 \mu \mathrm{M})$. Both records also show two distinct maxima in acidity centred on 1920 and 1970 CE (Fig. 4), with Tunu displaying higher acid- 

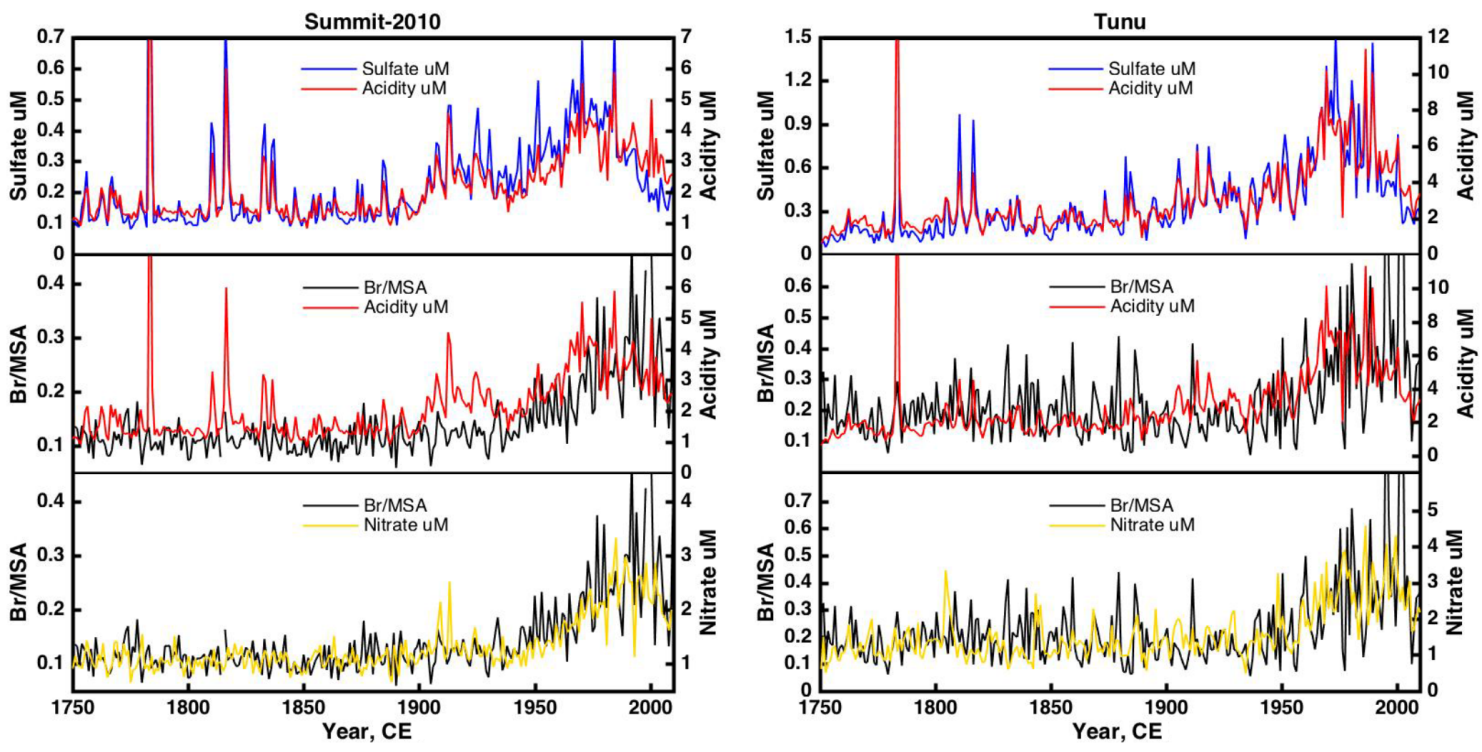

Figure 4. Comparison between the measured total sulfur (shown as sulfate) and acidity records from each ice core (top panels). The acidity record is dominated by the influence of the sulfur species until the early 21 st century when the $\mathrm{NO}_{x}$ pollution remains elevated whilst anthropogenic sulfur sources are depleted resulting in a slight relative elevation of the total acidity relative to total sulfur concentrations. The large spikes in the acidity and sulfur records are identified as volcanic events. The ice core records cover the period of the 1783 Laki eruption as well as the unknown 1909 eruption and Tambora eruption (Indonesia) in 1815 (Sigl et al., 2013). Comparison between Br / MSA and total acidity (centre panels) and nitrate $\left(\mathrm{NO}_{3}^{-}\right.$, bottom panels) measured in the ice cores. The $\mathrm{Br} / \mathrm{MSA}$ ratio follows the total acidity record closely except where the record is dominated by the sulfur component (e.g. early 1900s). Of the two major acidic species the Br / MSA follows the nitrate most closely at both ice core sites.

ity than Summit over the entire industrial period. Overlaid with the acidity is the total $\mathrm{S}$ record for both ice cores. The high correlation between the acidity and S records illustrates that the sulfur species are the dominant natural and anthropogenic acidic species in the ice cores. The trend in acidity closely follows the global $\mathrm{SO}_{2}$ emissions with maxima from coal $(\sim 1920 \mathrm{CE})$ and coal plus petroleum combustion ( 1970 CE) (Smith et al., 2011). After 1970 the records of acidity and $\mathrm{S}$ deviate. This deviation can be attributed to the presence of nitric acid that remains at a relatively high concentration in the late 20th century whilst sulfur species reduce in concentration (Fig. 4).

$\mathrm{NO}_{3}^{-}$concentrations show no trend during the preindustrial era in either ice core records, averaging $1.1( \pm 0.02) \mu \mathrm{M}$ and $1.3( \pm 0.03) \mu \mathrm{M}$ for Summit and Tunu, respectively. The higher signal-to-noise ratio in the Summit2010 record reveals a small peak in $\mathrm{NO}_{3}^{-}$concentrations centred on $\sim 1910$. The Tunu record also shows elevated $\mathrm{NO}_{3}^{-}$ concentrations over this period. However, the large variability in the signal makes it difficult to establish a higherresolution temporal trend. Both records clearly show a large increase in $\mathrm{NO}_{3}^{-}$after 1950, peaking in $\sim 1990$ and followed by a general decreasing trend with the average $\mathrm{NO}_{3}^{-}$levels still double that of pre-industrial concentrations: 2.1 and $2.3 \mu \mathrm{M}$ at Summit and Tunu, respectively.
The nitrate records from both sites follow the trend in Northern Hemisphere $\mathrm{NO}_{x}$ emissions with a peak in $\sim 1910$ and $1990 \mathrm{CE}-\mathrm{a}$ result of emissions from increases in both Northern Hemisphere fertilizer usage and biomass and fossil fuel combustion (Felix and Elliott, 2013).

\subsection{Air mass back trajectories}

Air-mass back-trajectory results demonstrate that air masses reaching the Summit-2010 site between March and July originate primarily from the south/south-east of the ice core site (Fig. 5a). Previous back trajectory analyses by Kahl et al. (1997) also linked individual spikes in their Summit MSA record to air masses that had passed over this same region of coast (SE Greenland) within the previous 1-3 days. Similar back trajectories were calculated for Summit-2010 up to heights of 500 and $10000 \mathrm{~m}$ (total column trajectory, Figs. 5a, S8a) illustrating that air masses that travel in the free troposphere and lower troposphere follow similar back trajectories and likely share the same source regions.

The results for Tunu indicate that air masses arrive primarily from the west coast of Greenland, passing over the Baffin Bay area, but there is also significant contribution from both the SE and NE (in May) coastal areas (Figs. 5b, S8b). Of these two secondary areas it is likely that aerosols transported from the NE would have a greater influence on the ice core concentrations due to proximity to the ice core site. 
(a) Summit boundary layer back trajectories
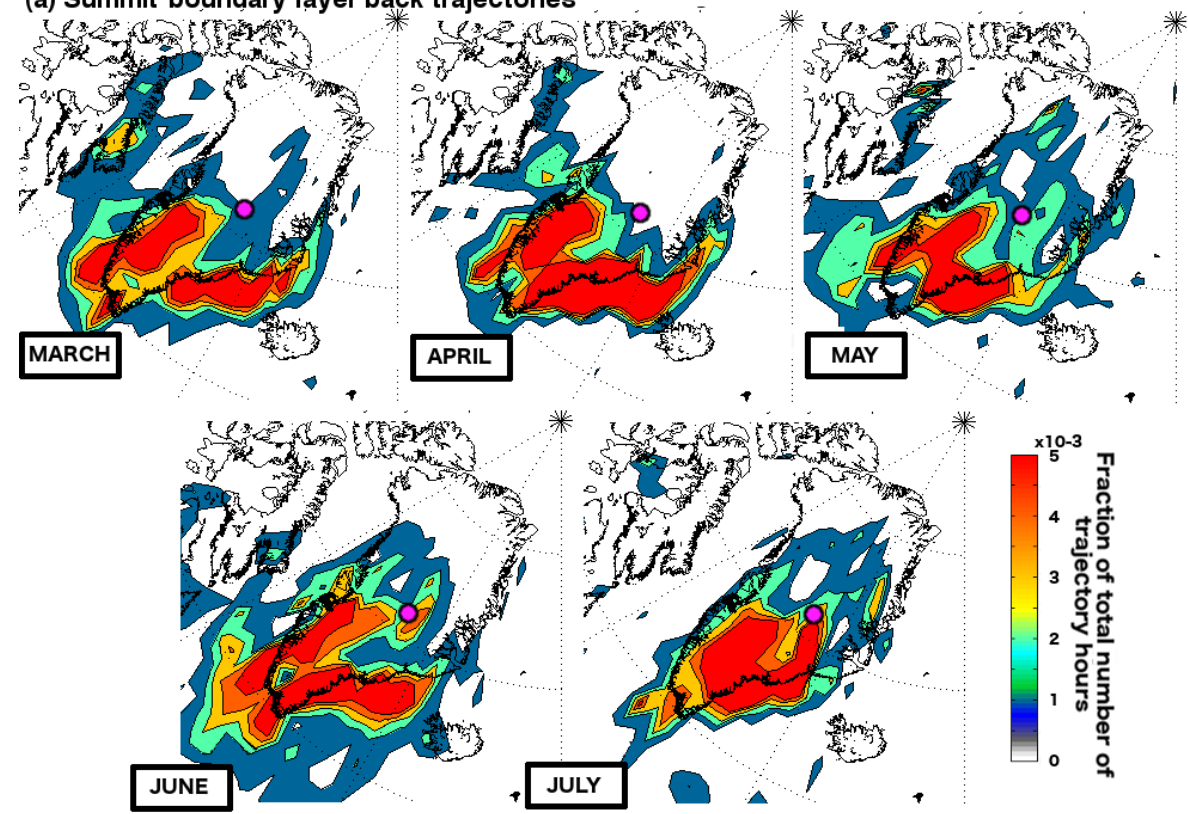

*

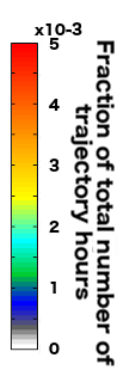

(b) Tunu boundary layer back trajectories
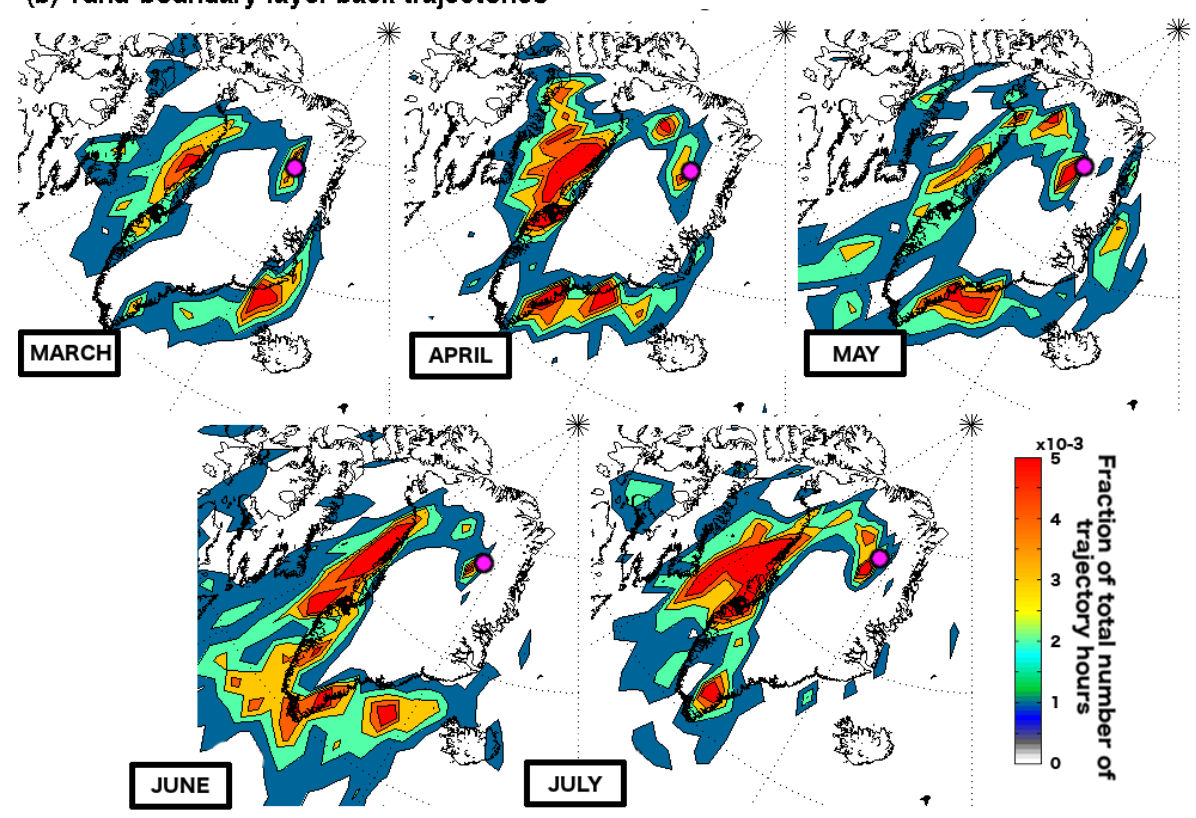

Figure 5. Air mass back trajectories from the (a) Summit-2010 and (b) Tunu ice core sites over the period 2005-2013 CE. Maps display the fraction of the total number of trajectory hours (ranging between 21400 and $25500 \mathrm{~h} \mathrm{month}^{-1}$ ) spent at altitudes under $500 \mathrm{~m}$. Back trajectories were allowed to travel for 10 days. New trajectories were started every $12 \mathrm{~h}$. Map grid resolution is $2^{\circ} \times 2^{\circ}$. Ice core locations are shown by a pink circle. Maps show that air masses consistently arrive at Summit from the SE Greenland coast with a smaller contribution from the SW coast. Air masses consistently arrive at Tunu from the western Greenland coast with a smaller contribution from the SE and NE coast. The air mass originating from the NE coast is most dominant in May and comparison with the total vertical column profile (Fig. S8) shows it is confined to lower altitudes unlike those from the west coast. 
Aerosol deposited at Tunu therefore represents a mixture of source regions, but are likely dominated by the NW Greenland Baffin Bay coastal region.

\subsection{MSA-sea ice correlations}

Locations which showed a SIC variability greater than $10 \%$ (the average estimated range of uncertainty in the satellite measurements) and have a significant correlation to MSA ( $t$ test, $p<0.05$ ) are displayed in Figs. S9 and S10 for the months of March-July. A greater emphasis must be placed on the post-1979 sea ice concentration maps as these were derived from passive microwave satellite data and, where available, operational ice chart data. The likely air mass source regions, as defined by the results of the air mass back trajectories, are indicated by the black bordered regions. Within these areas there is generally a negative correlation between SIC and MSA, particularly in the spring months and only small patches that show large correlation $(>0.4)$. The large areas of positive correlation along the east coast and in the western Barents Sea are striking for the Summit-2010 record, however, these areas are outside of the defined air mass source region and thus are unlikely to be contributing to the ice core aerosol records. The positive correlation is likely an artefact of the negative autocorrelation between sea ice conditions in this region and the SE coast source region (Fig. S11).

The effect of the estimated error in dating of the MSA records on the SIC correlation maps is explored in Fig. S12. By shifting the dating of the MSA records to either extreme of the dating error estimate and replotting the SIC correlation panels, it is clear the error in the dating of the MSA records does not affect the sign of the correlations displayed on the maps but can have an affect on the magnitude of the correlation found in different locations. This is likely a result of the peaks in the MSA record being shifted in or out of temporal coherence with peaks in SIC at the different locations.

Over the period 1900-2010 CE, highly significant correlation ( $t$ test, $p<0.001)$ is found between the annual ice core MSA and the amount of OWIP (representing the area of the marginal sea ice zone, Figs. $6 a$ and $7 \mathrm{a}$ lower panels) in these aerosol source areas. For both ice cores the source region OWIP trend is followed by the MSA. In the Summit-2010 ice core the highest correlation between annual MSA and monthly OWIP occurs in May $(r=0.58, p<0.001)$ though the following months through to July all show highly significant correlations (July $r=0.53, p<0.001$ ). For comparison, the May SIC correlation map is also shown as the upper panel in Fig. 6a. Figures $3 \mathrm{f}$ and S13 demonstrate that this time period (May-July) corresponds to the peak and then rapid decline in the amount of annual OWIP within the Summit-2010 aerosol source area because of the decreasing extent of sea ice. Rapid loss of sea ice reveals areas of biological activity previously capped by the ice, allowing surface-atmosphere exchange of DMS, resulting in the seasonal peak in atmospheric MSA correlation with the peak in the area of OWIP.

At Tunu, the highest correlation over the 1900-2012 CE period is found between annual MSA and annual OWIP $(r=$ $0.59, p<0.001)$, though the July OWIP shows the highest monthly correlation and is also highly significant $(r=0.41$, $p<0.002)$. For comparison, the July SIC correlation map is also shown as the upper panel in Fig. 7a. Due to the more northerly location of the Tunu aerosol source region, the sea ice pack in this region is generally less fractured and breakup occurs later in the year, with a sharp peak in OWIP occurring in July (Fig. S13). The higher stability of the ice pack throughout the year compared to that in the Summit-2010 source region is the likely reason the Tunu MSA shows highest correlation with the annual average of the OWIP. However, like Summit-2010 the highest monthly OWIP correlation occurs between the annual MSA and the timing of the maximum in annual OWIP (July).

Over the shorter, satellite era (1979-2012 CE) again Tunu shows strongest correlation between annual MSA and annual OWIP though at a much lower significance $(r=0.32$, $p<0.05$ ), and the highest monthly correlation occurs in March $(r=0.2, p<0.1)$ albeit with low significance. The significance of the Tunu correlation over this period can be dramatically increased (annual OWIP $r=0.54, p<0.001$; March OWIP $r=0.63, p<0.001$ ) if the closer, secondary aerosol source region (NE Greenland, $80-73^{\circ} \mathrm{N}, 20-0^{\circ} \mathrm{W}$ ) is assumed to also influence the site in equal proportion. March corresponds to the timing of increased insolation and thus the rapid increase in ice algal production (Leu et al., 2015). The shift from a July to March peak in the correlation of OWIP with annual Tunu MSA may be a result of the reduced overall sea ice extent (SIE) (and thus OWIP), influencing the timing of MSA production. Unfortunately, the post-depositional migration of the MSA signal within the ice cores masks any evidence of true seasonal MSA shifts. Summit-2010 also shows a much less significant monthly OWIP correlation with the annual MSA signal over this time period, with the most significant correlation again occurring in March $(r=0.4$, $p<0.02$ ). The greater significance of both the SIC-MSA and OWIP-MSA correlations at both sites over the longer time period is likely a result of the averaging of any MSA production or transport variability as well as the dominance of the low-frequency variability of both time series on the overall correlation.

\subsection{MSA-bromine relationship}

In an era where climate is driven by only natural forcings, chemical species that share a common source should show broadly consistent variability. This is evident in the preindustrial section of both ice core records where the relationship between MSA and $\mathrm{Br}$ (monitored as $\mathrm{Br}$ / MSA) remains constant over the entire period (Fig. 4) despite individual records going through step function changes. Us- 
(a)

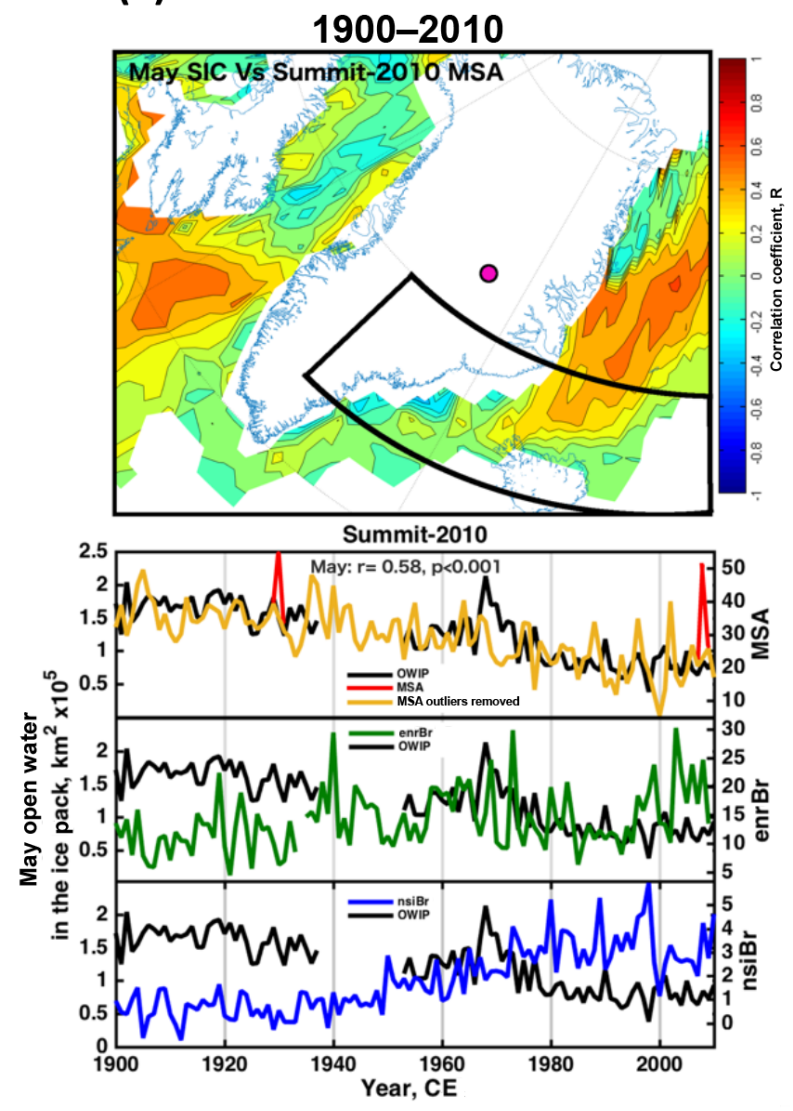

(b)

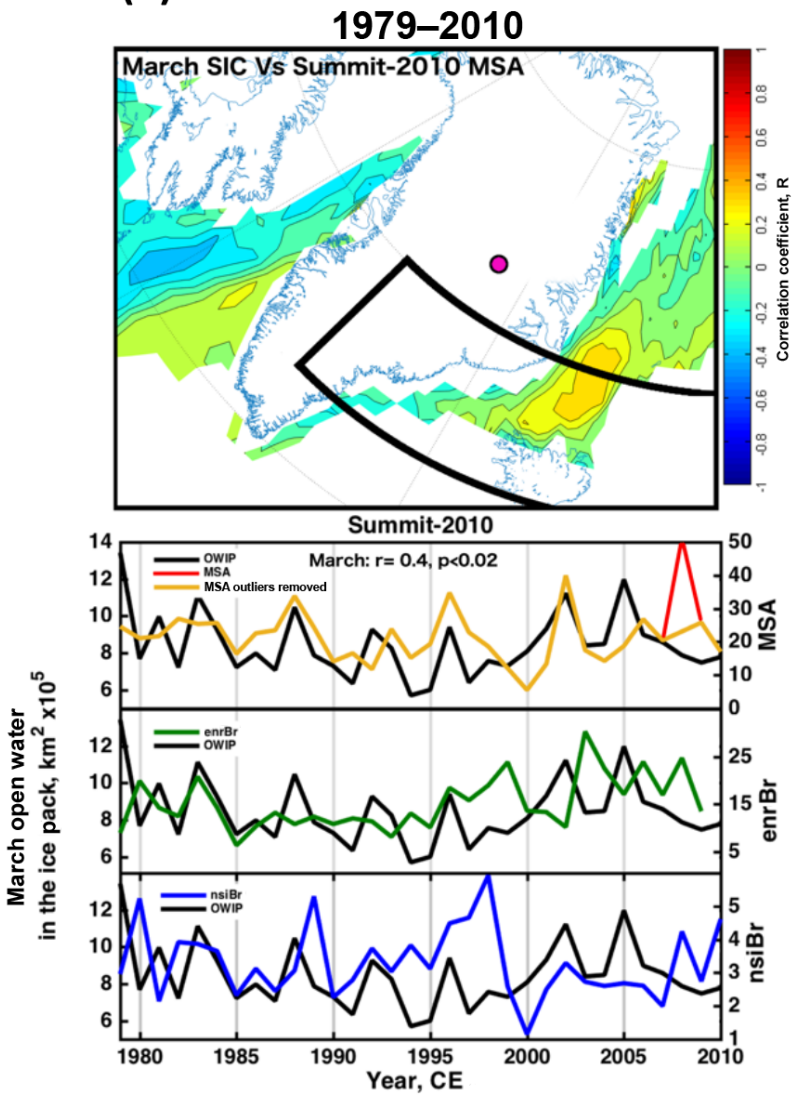

Figure 6. Upper panels: correlation map of monthly sea ice concentration (SIC) derived from the Summit-2010 ice core. The SIC map corresponds to the month which shows the highest OWIP correlation (lower panels) with the annual MSA. Other monthly maps are shown in Fig. S9. (a) HadISST1 ICE dataset from 1900 to 2010 CE correlated with annual records of MSA (with outliers removed). Only locations that showed a SIC variability greater than $10 \%$ and have a significant correlation $(t$ test, $p<0.05)$ are displayed. The area of sea ice that is the likely source of MSA (as indicated by the air mass trajectories) are outlined in black $\left(70-63^{\circ} \mathrm{N}, 0-45^{\circ} \mathrm{W}\right.$ ). (b) As for (a) but focused on the satellite period 1979-2010 CE. Lower panels: the correlation between the area of open water within the ice pack (OWIP) calculated within the black outlined areas shown on the upper maps and the annual MSA records (red) with outliers removed (orange) in nM. Summit2010 MSA shows a significant, positive correlation with the amount of OWIP during spring within the integrated regions over both time periods. The highest correlations were found for March over the 1979-2010 period and May for the 1900-2010 period. In (b) if the MSA source region is enlarged to $\left(70-63^{\circ} \mathrm{N}, 0-60^{\circ} \mathrm{W}\right)$ the March OWIP-MSA correlation increases slightly (from 0.38 to 0.4). The Summit-2010 enrBr(Na) and nsiBr records (in $\mathrm{nM}$ ) are also compared to the same OWIP records. Particularly over the longer time period, there is little correlation between the series.

ing a 25-year running average on all records, the correlation between MSA and Br over the pre-industrial period was calculated as Summit-2010: $r=0.282(p=0.0008)$; Tunu: $r=0.298(p=0.0004), n=138$. After $\sim 1930 \mathrm{CE}$, relative increases in $\mathrm{Br}$ concentrations cause the $\mathrm{Br} / \mathrm{MSA}$ ratio to increase above the stable pre-industrial levels by more than $160 \%$, reaching a peak in $\sim 2000 \mathrm{CE}$ at both sites.

Bromine in excess of what is expected from a purely sea ice source (non-sea-ice bromine, nsiBr) was calculated by comparison to the other sea ice proxy, MSA. A linear regression of MSA vs. Br was performed with the pre-industrial data (1750-1880 CE) to establish the relationship between the two proxies during an era free of anthropogenic forcing
(Fig. S14a, b). This relationship was then extrapolated into the period after $1880 \mathrm{CE}$ in order to estimate the amount of bromine sourced only from sea ice sources during the industrial era. The MSA record was smoothed with a ninth-order polynomial function before being used in the extrapolation to reduce the noise in the resultant record whilst maintaining the low-frequency trends (Fig. S14c, d). The nsiBr is thus the difference between the total bromine measured and the calculated, natural sea ice bromine (Figs. 8 and S14e, f); in contrast to $\mathrm{Br}_{\text {exc }}$ defined by Spolaor et al. (2016) as the amount of bromine in excess of the $\mathrm{Br} / \mathrm{Na}$ seawater ratio.

An estimate of the nsiBr is shown in Figs. 6, 7, and 8. By definition, nsiBr is essentially constant during the 
pre-industrial period, but during the industrial period $\mathrm{nsiBr}$ peaks, reaching a broad maximum between 1980 and $2000 \mathrm{CE}$ of $\sim 3.4$ and $1.9 \mathrm{nM}$ at Summit and Tunu, respectively.

\section{Discussion}

The significant correlation between variability of marginal sea ice zone (OWIP) area within the identified source regions and the MSA records suggests that MSA records can be used as a proxy for modern sea ice conditions in these areas. North Atlantic Oscillation proxy records developed in Greenland ice core records (Appenzeller et al., 1998) suggest that although the Northern Hemisphere climate phenomenon has shown variability over the past 200 years, its effect is damped in northern Greenland (Appenzeller et al., 1998; Weißbach et al., 2016) so we can assume that no major changes in atmospheric circulation patterns have occurred to change the source regions for the marine aerosols between the pre-industrial and industrial periods. If this assumption is true, our identification of MSA as a sea ice proxy (specifically a marginal sea ice zone proxy) may be valid for time periods both before and after 1850 at each ice core site.

The MSA records reveal that after $1820 \mathrm{CE}$ a gradual decline in sea ice occurred along the southern Greenland coast (reflected in the Summit-2010 core) and that this decline in sea ice did not extend significantly to the most northern Greenland coastline (reflected in the minimal change in Tunu MSA during this period). It is not unexpected that the Summit-2010 record would show the most dramatic changes in sea ice, since we have demonstrated that the Summit sea ice proxy (MSA) is sourced from the south-east Greenland coast - an area sensitive to climate changes as it is primarily covered by young, fragile sea ice. The timing of the sea ice decline is coincident with the end of the Little Ice Age (LIA), identified from $\delta^{18} \mathrm{O}$ ice core records as spanning the period 1420-1850 CE in Greenland (Weißbach et al., 2016). The dramatic dip in sea ice reflected in both the Tunu MSA and $\mathrm{Br}$ records at $1830 \mathrm{CE}$ (and also seen less dramatically in Summit) also appears in the multi-proxy reconstruction of sea ice extent in the western Nordic seas performed by Macias Fauria et al. (2010). This may be evidence of a $1830 \mathrm{CE}$ sea ice decline event isolated to the East Greenland coast as the ice core records do not replicate the other dramatic, early 20th century fluctuations observed in the latter part of the western Nordic seas reconstruction.

From the ice core records it appears that the greatest decline in Greenland sea ice began in the mid-20th century, dropping to levels that are unprecedented in the last 200 years. This decline is observed along the entirety of the Greenland coast. Sea ice declined first around the southern coast (from 1930 CE, reflected in Summit-2010), followed 54 years later by the more northern coastline (reflected in the Tunu record; see infection timings in Table S1). This sea ice decline is coincident with the sustained increase in greenhouse gases which has been identified as the major climate forcing and driver of increased global temperatures during the 20th century (Mann et al., 1998) and follows the same general trend in Arctic wide sea ice extent observed by Kinnard et al. (2008).

Bromine (more specifically bromine enrichment, Spolaor et al., 2014, and bromine excess, Spolaor et al., 2016) has also been suggested as a possible proxy for sea ice conditions, however the timing of the largest bromine aerosol deposition, in summer, does not coincide with the largest growth or extent of new sea ice. Sea ice begins to increase only at the end of summer as the fractures in the ice cover are relaminated and the ice edge begins to advance southward (see Fig. 3f). Figure S4 compares the record of total bromine and bromine enrichment (calculated relative to sodium, enrBr(Na)) from the Summit-2010 ice core. The major discrepancies between the two records occur when the total sodium signal has sharp maxima causing dips in the en$\mathrm{rBr}(\mathrm{Na})$ record in $\sim 1954$ and $1990 \mathrm{CE}$ and the magnitude of the low-frequency variability in $\operatorname{enrBr}(\mathrm{Na})$ is not as great as in the total bromine record. This is also demonstrated in Figs. 6 and 7 where the enrBr(Na) records are compared with the OWIP records. Whilst both series share high-frequency temporal features, over the longer term (1900-2010) the lowfrequency trend is dramatically different. We are not discounting enrBr(Na) as a viable proxy for sea ice conditions, however the use of $\mathrm{Na}$ to try and extract the pure sea water component of the $\mathrm{Br}$ is complicated by the fact that a lot of $\mathrm{Na}$ comes from the sea ice surface as well as from the open ocean. $\mathrm{Na}$ itself has been used as a sea ice proxy in several prominent studies (WAIS Divide Project Members, 2013; Wolff et al., 2003) because, like $\mathrm{Br}$, $\mathrm{Na}$ is incorporated into the snow on the surface of the sea ice and can be subsequently blown aloft to produce the atmospheric Na signal seen in the ice core. In addition, the $\mathrm{Na}$ concentration is fractioned upon the formation of the ice when mirabilite $\left(\mathrm{Na}_{2} \mathrm{SO}_{4}\right)$ is precipitated out of the brine solution at $-8^{\circ} \mathrm{C}$ (Abbatt et al., 2012).

The calculated, non-sea-ice bromine records (nsiBr) for both ice cores are shown in Figs. 6 and 7. Like the enrBr(Na) records, the nsiBr records share some of the high-frequency features of the OWIP records, however there is no significant correlation between $\mathrm{nsiBr}$ and the selected OWIP records over the short time period. This supports the supposition that the $\mathrm{nsiBr}$ record is indeed an extraction of the non-sea-ice component of bromine from the total bromine record. Over the longer time period there is a significant negative correlation between OWIP and $\mathrm{nsiBr}$ at both sites (Summit-2010: $r=-0.7, p<0.001$, and Tunu: $r=-0.22, p<0.02$ ). This result is likely an artifact of the positive correlation from the MSA records used to generate the nsiBr records.

So what is the summertime source of bromine? What is the cause of the increase in springtime bromine explosion events in the industrial era (see Fig. 3 lower panel) and why does 
(a)

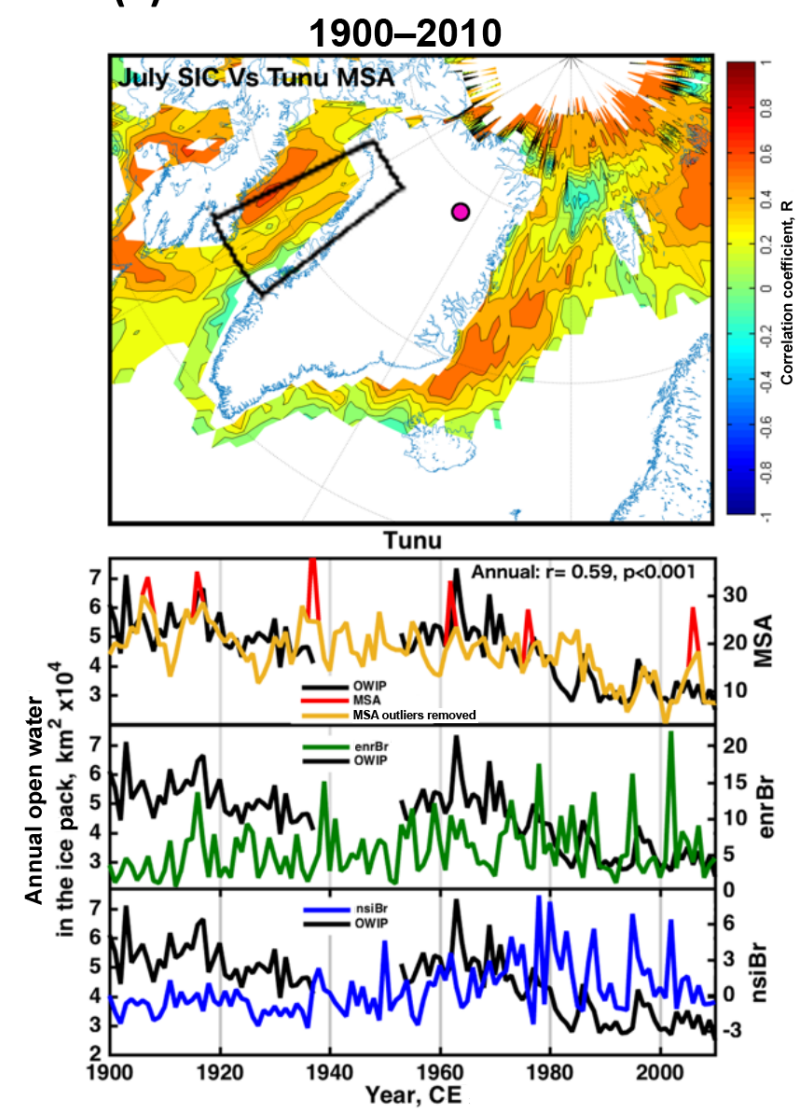

(b)

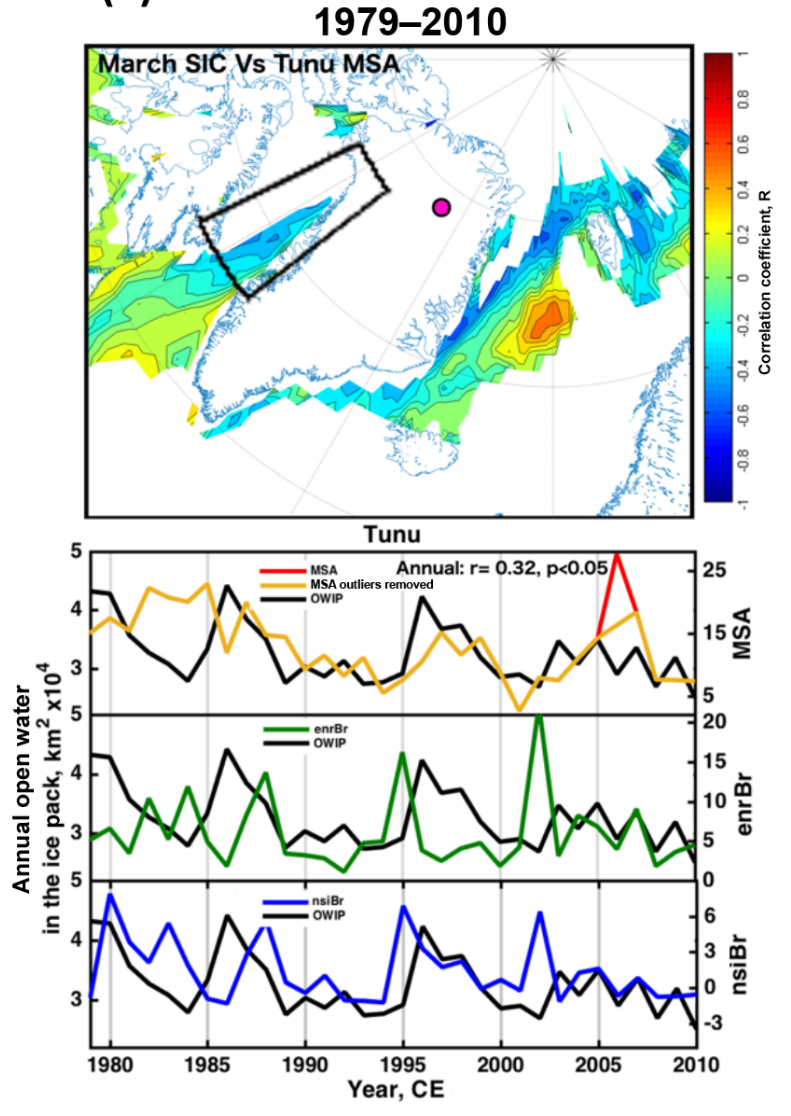

Figure 7. Upper panels: correlation maps of monthly sea ice concentration (SIC) derived from the Tunu ice core. (a) HadISST1 ICE dataset from 1900 to 2012 CE correlated with annual records of MSA. The monthly SIC map displayed corresponds to the month which shows the highest OWIP correlation (lower panels) with the annual MSA. Other monthly maps are shown in Fig. S10. Only locations that showed a SIC variability greater than $10 \%$ and have a significant correlation $(t$ test, $p<0.05)$ are displayed. The area of sea ice that is the likely source of MSA (as indicated by the air mass trajectories) are outlined in black (77-67 $\mathrm{N}, 62-50^{\circ} \mathrm{W}$ ). (b) As for (a) but focused on the satellite period 1979-2012 CE. Lower panels: the correlation between the area of open water within the ice pack (OWIP) calculated within the black outlined areas shown on the upper maps and the annual MSA records (red) with outliers removed (orange). $\mathrm{The} \mathrm{Tunu}$ enrBr( $\mathrm{Na}$ ) and nsiBr records (in $\mathrm{nM}$ ) are also compared to the same OWIP records and show poor correlation, particulary over the longer time period.

the bromine record deviate from the sea ice proxy record (MSA) around the same time? Possible sources of bromine and the factors which may effect the resultant bromine deposition flux are discussed below.

\subsection{Alternate sources of bromine}

\subsubsection{Combustion of coal}

Bromine is present in coal (Bowen, 1979; Sturges and Harrison, 1986) and coal burning is therefore a potential source of increased bromine deposition on the Greenland ice sheet over the period 1860-1940 (McConnell and Edwards, 2008). McConnell et al. (2007) demonstrated that pollution from the North American coal-burning era was deposited all over Greenland, leaving as its fingerprint large amounts of black carbon and toxic heavy metals. Sturges (1986) measured the relative concentrations of $\mathrm{Br}$ and $\mathrm{Pb}$ in particulates emitted from the stacks of coal-fired power stations and found a molar ratio $(\mathrm{Br}: \mathrm{Pb})$ ranging between $0.36-0.67: 1$. Figure 8 illustrates that at both Summit and Tunu the exPb (lead not from dust sources) preserved in the ice cores over the coalburning era $(\sim 1920)$ was less than $1 \mathrm{nM}$. This concentration implies that the upper limit to the amount of bromine deposited from coal combustion would be $0.67 \mathrm{nM}$ (assuming no loss of bromine from the particulates during transportation). This is an insignificant amount compared to the total $\mathrm{Br}$ signal preserved in the ice at this time. Coal combustion is not the major cause of the elevated industrial $\mathrm{Br}$ concentration. 

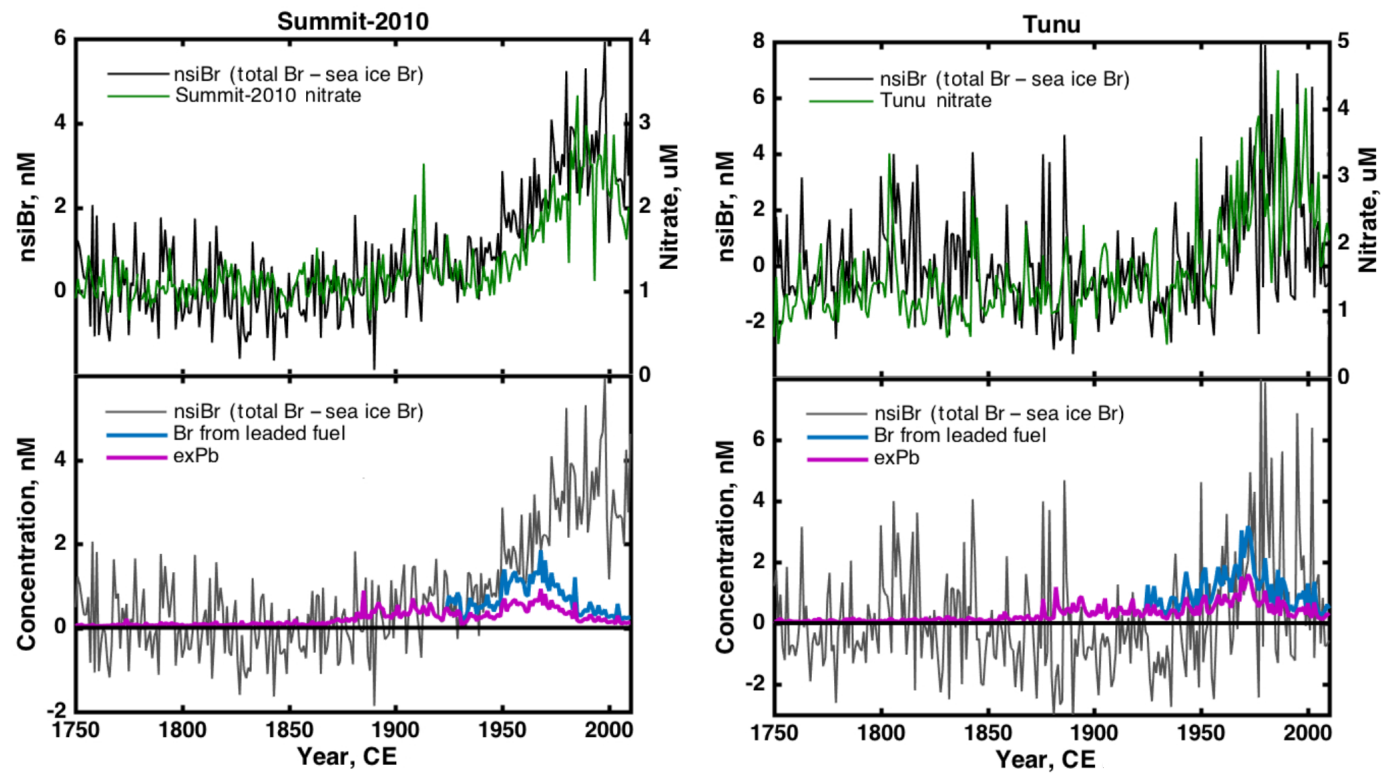

Figure 8. Upper panels: comparison between bromine in excess of what is expected from a purely sea ice source (nsiBr, black) and nitrate. The temporal similarities between the nitrate and $\mathrm{nsiBr}$ records are high and indicate that nitrate is a likely driving force for the enhanced release of bromine species from sea ice sources. Lower panels: comparison between the calculated nsiBr record and excess lead (exPb, purple) measured in the ice cores. The lower panels also show the upper limit to the amount of bromine that could be derived from leaded fuel combustion by assuming exPb: Br ratio of $1: 2$ after 1925 (blue). After 1970, when world consumption of leaded gasoline began to fall, nsiBr concentrations continued to rise at both ice core sites far above the concentrations that could be explained by leaded gasoline sources.

\subsubsection{Leaded gasoline}

The largest global, historical, anthropogenic source of bromine is thought to be the combustion of leaded gasoline. Large quantities of 1,2-dibromoethane (DBE) were added to leaded fuel as a scavenger for $\mathrm{Pb}$ preventing lead oxide deposition by converting it to volatile lead bromide salts as well as $\mathrm{CH}_{3} \mathrm{Br}$ (Berg et al., 1983; Nriagu, 1990; Oudijk, 2010). In $1925 \mathrm{CE}$ gasoline had a $\mathrm{Br}: \mathrm{Pb}$ molar ratio of $2: 1$ in a formulation which is now called "aviation fluid". The $\mathrm{Br}: \mathrm{Pb}$ molar ratio was reduced to $1: 1$ in the 1940s except in places such as the Soviet Union which continued to use aviation fluid for motor gasoline (Thomas et al., 1997). Although the consumption of leaded gasoline has been welldocumented, particularly in North America, the estimates of the emissions of bromine compounds from the combustion process are still unclear. Estimates of the amount of DBE that is converted into gaseous $\mathrm{CH}_{3} \mathrm{Br}$ range from 0.1 to $25 \%$ (Bertram and Kolowich, 2000) and direct measurements of exhaust fumes across NW England found a $\mathrm{Br}: \mathrm{Pb}$ ratio of between $0.65-0.8: 1$ in the airborne particulates (Sturges and Harrison, 1986).

The ratio of $\mathrm{Br}: \mathrm{Pb}$ in the gasoline formulae can therefore be used only as an upper limit to predict the $\mathrm{Br}: \mathrm{Pb}$ ratio in gasoline combustion aerosols transported to the ice core sites. Figure 8 shows a comparison between $n s i B r$ and ex $\mathrm{Pb}$ measured in each ice core. Also illustrated is the upper limit of the amount of bromine expected from gasoline sources as- suming the $2: 1 \mathrm{Br}: \mathrm{Pb}$ ratio for aviation gasoline over the whole leaded gasoline era. Worldwide leaded gasoline emissions were estimated to have peaked in 1970 CE (Thomas et al., 1997) - an assumption that is supported by the observed timing of the exPb maximum observed in both ice cores. Whilst it is likely that leaded fuel contributed to the increased bromine observed between 1925 and 1970, it is clear that it was not the only contributor to the nsiBr record, particularly after 1970 when the $\mathrm{nsiBr}$ record continues to rise despite a worldwide decline in leaded fuel consumption. The disparity between the exPb and $\mathrm{nsiBr}$ records suggests the driving force for the enhanced emission of $\mathrm{Br}$ was still active and increasing after 1970.

\subsubsection{Seasonal salinity changes}

Younger sea ice surfaces such as frost flowers, new and first year sea ice have a higher salinity and thus have higher bromine concentrations than older sea ice surfaces (Hunke et al., 2011). The salinity of sea ice is at its maximum at the start of the winter season after which surface salinity slowly diminishes due to gravitational draining (Hunke et al., 2011). As summer approaches, ice continues to undergo desalination due to melting of surface snow which percolates through the ice (Hunke et al., 2011). Satellite observations that the $\mathrm{BrO}$ flux from the sea ice declines over summer (despite increasing insolation) is likely due to the combined reduction in young sea ice area and in ice salinity. Ocean surface 
salinity decreases in the summer due to the increased meteoric water flux and melting of desalinated sea ice. Salinity increases are therefore unlikely to be the sole cause of the nsiBr flux observed in the ice core records and the observed summer maximum in bromine.

\subsubsection{Organic bromine species}

Gaseous bromocarbons can be a source of inorganic bromine to the snowpack when they react with $\cdot \mathrm{OH}$ or to a lesser extent with $\cdot \mathrm{NO}_{x}$ or by photolysis (Kerkweg et al., 2008; WMO, 1995) to form the less reactive species $\mathrm{HBr}, \mathrm{BrNO}_{3}$, and $\mathrm{HOBr}$. These species can then be washed out of the atmosphere and deposited on the snow surface due to their high solubility (Fan and Jacob, 1992; Sander et al., 1999; Yung et al., 1980).

The predominant source of gaseous bromine in the atmosphere is methyl bromide, $\mathrm{CH}_{3} \mathrm{Br}$ (WMO, 2003). The major modern sources of $\mathrm{CH}_{3} \mathrm{Br}$ are fumigation, biomass burning, leaded fuel combustion, coastal marshes, wetlands, rapeseed, and the oceans (WMO, 2003). The ocean is also a major sink for $\mathrm{CH}_{3} \mathrm{Br}$, the temperature-sensitive dissolution occurring through hydrolysis and chloride ion substitution to form bromide (WMO, 1995). Approximately $30 \%$ of $\mathrm{CH}_{3} \mathrm{Br}$ was from industrial emissions at the time of the global peak in the $\mathrm{CH}_{3} \mathrm{Br}$ mixing ratio (1996-1998) (Montzka and Reimann, 2010). The timing of the massive increases in $\mathrm{nsiBr}$ seen at both ice core sites coincides with the timing of maximum anthropogenic emissions of $\mathrm{CH}_{3} \mathrm{Br}$. However, the estimated $2.7 \mathrm{ppt}$ increase in global tropospheric $\mathrm{CH}_{3} \mathrm{Br}$ above preindustrial levels equates to only $\sim 3.7 \mathrm{ppt}(0.05 \mathrm{nM}) \mathrm{Br}$ incorporated into the snowpack (assuming 100\% conversion efficiency of $\mathrm{CH}_{3} \mathrm{Br}$ in soluble $\mathrm{Br}$ species). This level is far less than the $2-5 \mathrm{nM}$ increase in $\mathrm{nsiBr}$ observed in the ice cores during the industrial period.

Bromoform $\left(\mathrm{CHBr}_{3}\right)$ is emitted from vegetation such as marine phytoplankton and seaweed. It has the largest global flux of all the bromocarbons (estimated at almost 5 times that of $\mathrm{CH}_{3} \mathrm{Br}$ (Kerkweg et al., 2008). However, it is very short-lived (atmospheric lifetime of $\sim 17$ days (Ordóñez et al., 2012) and thus is confined to the marine boundary layer. Inorganic bromine formed from the destruction of $\mathrm{CHBr}_{3}$ would therefore be representative of only local sources of organic bromine. The biological seasonal cycle maximises the production of $\mathrm{CHBr}_{3}$ in summer and concentrations are greatly reduced but not negligible in winter (tidal forcing also influences bromocarbon emission by allowing coastal algae to dry out (Kerkweg et al., 2008). The season of Arctic sea ice algae productivity is confined by limitations in available sunlight and nutrients resulting in a mid-to-late spring maxima - depending upon site location (Leu et al., 2015) - as is reflected in the seasonality of the MSA record. Direct transport of bromine enriched aerosols from these algal sources to the ice core sites again cannot explain the summer maximum of bromine observed in the ice. In addition to the incoherence of the seasonality of the bromine ice core signal, to-date biogenic sources have been considered insignificant sources of bromine in the Arctic marine boundary layer compared with the inorganic bromine source from sea salts (Simpson et al., 2007).

\subsection{Cause of the springtime increase in bromine flux}

\subsubsection{Bromine explosion events}

Spring is the time of "bromine explosion" events above sea ice. Sea salt aerosols passing through these $\mathrm{BrO}$ plumes can become enriched with bromine by adsorbing the gaseous species (Fan and Jacob, 1992; Langendörfer et al., 1999; Lehrer et al., 1997; Moldanová and Ljungström, 2001; Sander et al., 2003). Nghiem (2012) showed that these bromine rich air masses can then be elevated above the planetary boundary layer and transported hundreds of kilometres inland. Increasing the frequency and duration of the bromine explosion events would therefore likely increase the amount of bromine delivered to the ice core sites during spring without influencing the total aerosol flux and thus explain the shift in the bromine seasonal concentrations from a purely summer to a broad spring-summer maxima (Fig. 3).

Springtime field studies at Ny Ålesund, Svalbard have shown positive correlation between atmospheric filterable bromine species and elevated levels of sulfate and nitrate (Langendörfer et al., 1999; Lehrer et al., 1997) suggesting that acidic, anthropogenic pollution may be the driver of the observed increases in annual bromine enrichment during the industrial period and seasonal shift.

\subsubsection{Acidity effects on debromination}

In remote, relatively clean environments such as the Arctic, even small increases in acidity are thought to affect the cycling of bromine in the snowpack (Finlayson-Pitts, 2003; Pratt et al., 2013; Sander et al., 1999). In the laboratory, increasing the acidity of frozen (Abbatt et al., 2010) and liquid salt solutions (Frinak and Abbatt, 2006; George and Anastasio, 2007) increased the yield of gas-phase $\mathrm{Br}_{2}$ whilst at the same time increasing the solubility of other bromine species, such as $\mathrm{HBr}$. The uptake efficiency of $\mathrm{HBr}$ by acidic sulfate aerosols, for example, is estimated at $80 \%$ compared to $30 \%$ for sea salt aerosols (Parrella et al., 2012). Interestingly, Abbatt (1995) demonstrated that $\mathrm{HBr}$ is more than 100 times more soluble in supercooled sulfuric acid solutions than $\mathrm{HCl}$. This may explain the cause of bromine enrichment in the aerosol measured in the ice cores relative to the more abundant chlorine (Fig. S3). The results of both the laboratory and field studies suggest that increasing snow/ice acidity in the Arctic will likely enhance springtime bromine explosion events above the sea ice whilst the increase in solubility allows the termination products of the explosion to be transported away from the sites on the surface of acidic 
aerosols. Increasing springtime bromine aerosol concentrations would increase the average annual bromine concentrations deposited on the ice sheet and could explain the $\mathrm{nsiBr}$ records observed in both ice cores.

There are also significant periods over which the calculated $\mathrm{nsiBr}$ record shows negative values (e.g. 1815-1870 CE in Summit-2010 and 1860-1940 CE in Tunu). The negative values are a result of the total $\mathrm{Br}$ being less than that calculated by interpolation from the smoothed MSA record. Though the sources of $\mathrm{Br}$ and MSA are linked - which is what provides the similarities between the general lowfrequency trend of the two species - the atmospheric processing, transport and deposition of the two species may be modified by different variables such as changes in atmospheric acidity, for example. These variables cause the short-term differences between the MSA and total $\mathrm{Br}$ records preserved in the ice so we believe it is not unreasonable to expect negative values in the calculated non-sea-ice $\mathrm{Br}$ record when the MSA and total $\mathrm{Br}$ are close (essentially no $\mathrm{nsiBr}$ ).

Figure 9 illustrates that of the two dominant acidic species preserved in the ice, $\mathrm{HNO}_{3}$ (represented by nitrate) shows the highest correlation to total bromine over sub-decadal time scales at both ice core sites. Records were detrended with an 11-year running average before comparison to isolate the high-frequency components of each record. The brominesulfuric acid (represented by sulfate) correlation is not significant. This is primarily because there is no bromine response to the dominant volcanic sulfate spikes throughout the record. The large spikes in sulfate concentrations did not cause a depletion of bromine preserved in the snowpack (Fig. 9). This result might be expected if the increased acidity caused more bromine to volatize. These results suggest that $\mathrm{HNO}_{3}$ is the most influential of the MBL acidic species in the processing and transport of $\mathrm{Br}$ on aerosols in the MBL.

\subsection{3 $\mathrm{NO}_{x}$ and links to bromine}

The snow and atmospheric chemistries of bromine and nitrate $\left(\mathrm{NO}_{3}^{-}\right)$are tightly linked. $\mathrm{NO}_{3}^{-}$is one of the main sources of the $\cdot \mathrm{OH}$ radical. The $\cdot \mathrm{OH}$ radical can oxidize bromide salts and cause the release of gas-phase bromine species (Abbatt et al., 2010; Chu and Anastasio, 2005; George and Anastasio, 2007; Jacobi et al., 2014). Morin et al. (2008) observed that the majority of nitrate that is deposited to the snow surface is of the form $\mathrm{BrNO}_{3}$ in coastal Arctic boundary layer. $\mathrm{BrNO}_{3}$ forms by gas-phase reaction of $\mathrm{BrO}$ and $\mathrm{NO}_{2} . \mathrm{BrNO}_{3}$ is quickly adsorbed back onto the snow and aerosol surfaces due to its high solubility. The heterogeneous hydrolysis of $\mathrm{BrNO}_{3}$ to again release bromine species back into the gas phase has also been observed (Parrella et al., 2012) and can occur both during sunlight hours as well as in the dark (Sander et al., 1999). However, the study by Thomas et al. (2012) into the cycling of $\mathrm{NO}_{x}$ and bromine species in the snowpack at Summit concluded that the presence of snow
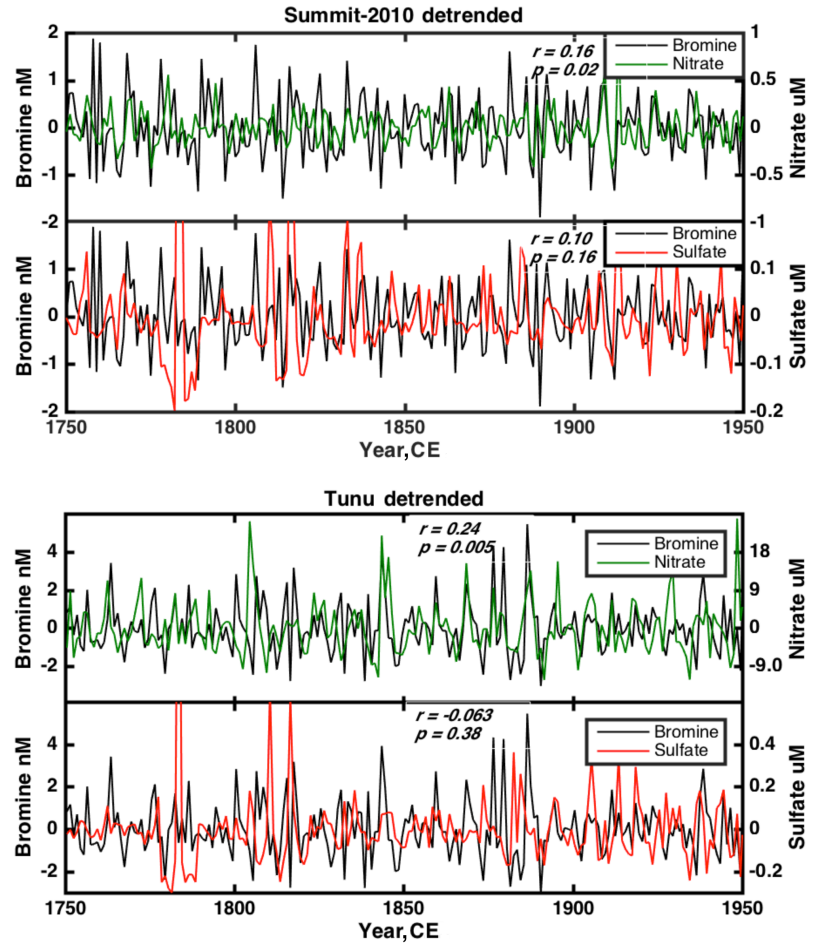

Figure 9. High-frequency comparison between the annual bromine, nitrate and sulfate records measured in the ice cores. Each series has been detrended with an 11-year running average before comparison to remove the low-frequency changes in each record. The correlation is highest between bromine and nitrate at both sites. The $r$ value for bromine vs. nitrate at Summit increases in significance $(r=0.24, p=0.001)$ when the entire period (1750-2010) is considered. At both sites there is a close relationship between the variability in the nitrate and bromine due to their intimate relationship during emission from the sea ice, transport and deposition onto the snowpack. The correlation between sulfate (or indeed bulk acidity) and bromine is not significant over any of the time periods shown at either site. Particularly evident is the non-response of the bromine signal to the sulfur rich volcanic events as described in Sect. 4.2.2.

$\mathrm{NO}_{3}^{-}$would suppress the emission of $\mathrm{BrO}$ from the snowpack and into the interstitial air.

In spring, when the greatest concentrations of $\mathrm{BrO}$ are observed over the sea ice the atmospheric concentrations of $\mathrm{NO}_{x}$ species is rising. After $1900 \mathrm{CE}$ there was, on average, a $60 \%$ increase in spring $\mathrm{NO}_{3}^{-}$concentrations observed in Summit-2010 ice core (Fig. 3d) which, as discussed in Sect. 4.2.1, if reflected in the concentration of acidic aerosols landing on the sea ice (specifically $\mathrm{HNO}_{3}$ concentrations), would enhance the emission of $\mathrm{BrO}$ into the MBL. Satellite imagery shows that bromine in the form of $\mathrm{BrO}$ is confined primarily to the atmosphere above sea ice (Schönhardt et al., 2012; Wagner et al., 2001) but the presence of measurable bromine concentration hundreds of kilometres inland preserved in the ice cores demonstrates that the bromine must be transported inland, just not in the form of $\mathrm{BrO}$. The reaction 
of atmospheric $\mathrm{NO}_{2}$ with $\mathrm{BrO}$ can produce the highly soluble $\mathrm{BrNO}_{3}$, which will preserve the bromine in the aerosol allowing it to be transported inland. If there are high $\mathrm{NO}_{3}^{-}$ concentrations at the deposition site this will aid in fixing the bromine into the snowpack. This is supported by the observation that $\mathrm{NO}_{3}^{-}$snowpack concentrations reach a maximum in summer, coherent with bromine snowpack concentrations even though maximum $\mathrm{Br}$ emission from the sea ice occurs in spring. So it appears that $\mathrm{NO}_{x}$ in its different forms, as $\mathrm{NO}_{2}$, $\mathrm{NO}_{3}^{-}, \mathrm{HNO}_{3}$ or $\mathrm{BrNO}_{3}$, is intertwined with $\mathrm{Br}$ as it cycles between the gas and condensed phases and as it is transported from sea ice source to deposition site. Elevated levels of $\mathrm{NO}_{x}$ over the Arctic could thus be the cause of the deviation of the bromine record from the MSA sea ice proxy record.

The high correlation between the pre-industrial (1750$1850 \mathrm{CE}$ ) $\mathrm{NO}_{3}^{-}$and $\mathrm{Br}$ records (Fig. 9) supports this observation of co-transport and sink of $\mathrm{Br}$ and $\mathrm{NO}_{3}^{-}$into the snowpack, though the natural sources of each are distinctly different. In the industrial era, the low-frequency temporal profile of the total bromine and nitrate records differ considerably, particularly at Summit (Fig. S15), apparently questioning the tight relationship observed before 1850 . However, the positive correlation between the nitrate and the $\mathrm{Br} / \mathrm{MSA}$ (Fig. 4) and $\mathrm{nsiBr}$ (Fig. 8) records is striking at both sites. The large relative increase in bromine (compared with MSA) during the era of high $\mathrm{NO}_{x}$ pollution may point to a non-sea-ice source of bromine linked to nitrate emissions or simply an increased springtime emission and summertime deposition of $\mathrm{Br}$ from sea ice sources.

Bromine and $\mathrm{NO}_{x}$ species shared a common source in the 20th century through the combustion of leaded gasoline (Sect. 4.1.2). As discussed above, we observe that leaded fuel pollution reaching the Arctic began to decline after 1970 in line with reduced global consumption, but the amount of bromine in excess of natural sources (nsiBr) continued to increase - following the trends in $\mathrm{NO}_{x}$ pollution (Fig. 8a). The continued increase in $\mathrm{NO}_{x}$ despite the decline in leaded fuel combustion is attributed primarily to biomass burning, soil emissions, and unleaded fossil fuel combustion (Lamarque et al., 2013). As the leaded fuel source of bromine began to decline, organic bromine pollutants continued to increase, as was discussed in Sect. 4.1.4. This can only account for a small fraction of the observed $\mathrm{Br}$. The continued correlation between nitrate and nsiBr despite the decoupling of nitrate and bromine anthropogenic sources after 1970 suggests that nitrate pollution is likely influencing the processing of local, natural sources of bromine in the polar MBL, in effect increasing the mobility of the bromine and thus its flux and preservation in the ice sheet.

\subsubsection{Consequences of nitrate-driven increased bromine mobility in the Arctic}

Plumes of $\mathrm{BrO}$ emitted from sea ice regions have been linked to mercury deposition events which lead to an increase in the bioavailability of toxic mercury species in polar waters (Parrella et al., 2012). Increased springtime mobilization of bromine from the sea ice induced by anthropogenic nitrate could therefore increase the frequency and duration of these events and thus the mercury toxicity of the oceans. Increased atmospheric bromine concentrations would also increase the frequency of ozone-depletion events (Simpson et al., 2007) thereby altering the oxidative chemistry of the polar MBL.

Whilst several studies have begun to explore bromine records from ice cores as a proxy for past sea ice conditions, the results of this study demonstrate that in an era of massive increases in atmospheric acidity the natural relationship between bromine and sea ice conditions can become distorted, precluding it from being an effective modern-day Arctic sea ice proxy.

\section{Conclusion}

In this study we have shown that high-resolution MSA measurements preserved in ice cores can be used as a proxy for sea ice conditions (specifically the size of the marginal sea ice zone) along specific sections of the Greenland coast. The MSA records show that sea ice began to decline at the end of the LIA and again, more dramatically during the industrial period. Also, unsurprisingly, the changes in sea ice conditions in the northern sites have been less dramatic than along the southern coastline. Comparison between the 260year records of bromine and MSA presented in this study allow us to show that in the pre-industrial era bromine concentrations preserved in the Greenland ice sheet are also likely linked to the local sea ice conditions. With the decline of sea ice in the modern era and the dramatic increase in acidic pollutants reaching the Arctic the sea ice-bromine connection is distorted, precluding it from being an effective, direct sea ice proxy during the industrial era. The introduction of $\mathrm{NO}_{x}$ pollution, in particular, into the clean Arctic environment promotes mobilization of bromine from the sea ice, which in turn increases the bromine enrichment of the sea salt aerosols, forcing more bromine inland (particularly in spring) than would occur naturally. Nitrate has also been linked with the mechanism for preservation of bromine in the snowpack. The summertime maximum of nitrate may therefore be responsible for the observed summertime bromine maximum preserved in the ice cores. Whilst Northern Hemisphere pollution may prevent bromine from being an effective modern-day sea ice proxy in the Arctic, in Antarctica the anthropogenic flux of nitrate species is thought to be small in comparison with natural sources (Wolff, 2013), leaving room for the possibility that bromine may still be an effective proxy for local Antarctic sea ice conditions and for pre-industrial sea ice reconstructions. 


\section{Data availability}

The raw Tunu data sets are available at the NSF Arctic Data Center website (McConnell, 2016).

The data used in the paper are also supplied in Excel spreadsheet format as a Supplement.

\section{The Supplement related to this article is available online at doi:10.5194/cp-13-39-2017-supplement.}

Author contributions. The paper was written and the data analysis performed by Olivia J. Maselli, with expert editing by Eric Saltzman. Ice cores supplied by Joseph R. McConnell. Tunu ice core was collected and processed by Olivia J. Maselli, Joseph R. McConnell, Nathan J. Chellman, Michael Sigl, and Rachael H. Rhodes under the leadership of Beth Bergeron. Ice cores dated by Michael Sigl and Joseph R. McConnell. The ICP-MS and CFA measurements performed by Olivia J. Maselli, Joseph R. McConnell, Nathan J. Chellman, Lawrence Layman, Daniel Pasteris, and Michael Sigl. The MSA measurements were designed and performed by Mackenzie Grieman and Eric Saltzman.

Acknowledgement. This research was funded by the National Science Foundation, grant numbers 1023672 and 1204176.

Edited by: K. Goto-Azuma

Reviewed by: two anonymous referees

\section{References}

Abbatt, J., Oldridge, N., Symington, A., Chukalovskiy, V., McWhinney, R. D., Sjostedt, S., and Cox, R. A.: Release of gasphase halogens by photolytic generation of $\mathrm{OH}$ in frozen halidenitrate solutions: an active halogen formation mechanism?, J. Phys. Chem. A, 114, 6527-6533, doi:10.1021/jp102072t, 2010.

Abbatt, J. P. D.: Interactions of $\mathrm{HBr}, \mathrm{HCl}$, and $\mathrm{HOBr}$ With Supercooled Sulfuric- Acid-Solutions of Stratospheric Composition, J. Geophys. Res., 100, 14009-14017, 1995.

Abbatt, J. P. D., Thomas, J. L., Abrahamsson, K., Boxe, C., Granfors, A., Jones, A. E., King, M. D., Saiz-Lopez, A., Shepson, P. B., Sodeau, J., Toohey, D. W., Toubin, C., von Glasow, R., Wren, S. N., and Yang, X.: Halogen activation via interactions with environmental ice and snow in the polar lower troposphere and other regions, Atmos. Chem. Phys., 12, 6237-6271, doi:10.5194/acp-12-6237-2012, 2012.

Abram, N. J., Wolff, E. W., and Curran, M. A. J.: A review of sea ice proxy information from polar ice cores, Quaternary Sci. Rev., 79, 168-183, doi:10.1016/j.quascirev.2013.01.011, 2013.

Appenzeller, C., Schwander, J., Sommer, S., and Stocker, T. F.: The North Atlantic Oscillation and its imprint on precipitation and ice accumulation in Greenland, Geophys. Res. Lett., 25, 1939, doi:10.1029/98GL01227, 1998.
Arienzo, M. M., McConnell, J. R., Chellman, N., Criscitiello, A. S., Curran, M., Fritzsche, D., Kipfstuhl, S., Mulvaney, R., Nolan, M., Opel, T., Sigl, M., and Steffensen, J. P.: A Method for Continuous 239Pu Determinations in Arctic and Antarctic Ice Cores, Environ. Sci. Technol., 50, 7066-7073, doi:10.1021/acs.est.6b01108, 2016.

Barrie, L. A., Hoff, R. M., and Daggupaty, S. M.: The influence of mid-latitudinal pollution sources on haze in the Canadian arctic, Atmos. Environ., 15, 1407-1419, doi:10.1016/00046981(81)90347-4, 1981.

Berg, W. W., Sperry, P. D., Rahn, K. A., and Gladney, E. S.: Atmospheric Bromine in the Arctic, J. Geophys. Res., 88, 6719-6736, doi:10.1029/JC088iC11p06719, 1983.

Bertram, F. J. and Kolowich, J. B.: A study of methyl bromide emissions from automobiles burning leaded gasoline using standardized vehicle testing procedures, Geophys. Res. Lett., 27, 14231426, doi:10.1029/1999GL011008, 2000.

Bigler, M., Wagenbach, D., Fischer, H., Kipfstuhl, J., Miller, H., Sommer, S., and Stauffer, B.: Sulphate record from a northeast Greenland ice core over the last 1200 years based on continuous flow analysis, Ann. Glaciol., 35, 250-256, doi:10.3189/172756402781817158, 2002.

Bowen, H. J. M. (Ed.): Environmental chemistry of the elements, BOOK, Academic Press, London, New York, 1979.

Chellman, N. J., Hastings, M. G., and McConnell, J. R.: Increased nitrate and decreased $\delta^{15} \mathrm{~N}-\mathrm{NO}_{3}^{-}$in the Greenland Arctic after 1940 attributed to North American oil burning, The Cryosphere Discuss., doi:10.5194/tc-2016-163, in review, 2016.

Chen, Q. S., Bromwich, D. H., and Bai, L.: Precipitation over Greenland retrieved by a dynamic method and its relation to cyclonic activity, J. Climate, 10, 839-870, 1997.

Chu, L. and Anastasio, C.: Formation of hydroxyl radical from the photolysis of frozen hydrogen peroxide, J. Phys. Chem. A, 109, 6264-6271, doi:10.1021/jp051415f, 2005.

Curran, M. A. J. and Jones, G. B.: Dimethyl sulfide in the Southern Ocean: Seasonality and flux, J. Geophys. Res., 105, 20451, doi:10.1029/2000JD900176, 2000.

Curran, M. A. J., van Ommen, T. D., Morgan, V. I., Phillips, K. L., and Palmer, A. S.: Ice core evidence for Antarctic sea ice decline since the 1950s., Science, 302, 1203-1206, doi:10.1126/science.1087888, 2003.

Draxler, R. R. and Hess, G. D.: An Overview of the HYSPLIT_4 Modelling System for Trajectories, Dispersion, and Deposition, Aust. Meteorol. Mag., 47, 295-308, 1998.

Fan, S.-M. and Jacob, D. J.: Surface ozone depletion in Arctic spring sustained by bromine reactions on aerosols, Nature, 359, 522-524, doi:10.1038/359522a0, 1992.

Felix, J. D. and Elliott, E. M.: The agricultural history of humannitrogen interactions as recorded in ice core $\delta^{15}{\mathrm{~N}-\mathrm{NO}_{3}^{-}}^{-}$, Geophys. Res. Lett., 40, 1642-1646, doi:10.1002/grl.50209, 2013.

Finlayson-Pitts, B. J.: The Tropospheric Chemistry of Sea Salt: A Molecular-Level View of the Chemistry of $\mathrm{NaCl}$ and $\mathrm{NaBr}$, Chem. Rev., 103, 4801-4822, doi:10.1021/cr020653t, 2003.

Fischer, H. and Wagenbach, D.: Large-scale spatial trends in recent firn chemistry along an east-west transect through central Greenland, Atmos. Environ., 30, 3227-3238, doi:10.1016/13522310(96)00092-1, 1996.

Frinak, E. K. and Abbatt, J. P. D.: $\mathrm{Br}_{2}$ production from the heterogeneous reaction of gas-phase $\mathrm{OH}$ with aqueous salt solutions: 
Impacts of acidity, halide concentration, and organic surfactants, J. Phys. Chem. A, 110, 10456-10464, doi:10.1021/jp063165o, 2006.

George, I. J. and Anastasio, C.: Release of gaseous bromine from the photolysis of nitrate and hydrogen peroxide in simulated sea-salt solutions, Atmos. Environ., 41, 543-553, doi:10.1016/j.atmosenv.2006.08.022, 2007.

Hunke, E. C., Notz, D., Turner, A. K., and Vancoppenolle, M.: The multiphase physics of sea ice: a review for model developers, The Cryosphere, 5, 989-1009, doi:10.5194/tc-5-989-2011, 2011.

Jacobi, H. W., Kleffmann, J., Villena, G., Wiesen, P., King, M., France, J., Anastasio, C., and Staebler, R.: Role of nitrite in the photochemical formation of radicals in the snow, Environ. Sci. Technol., 48, 165-172, doi:10.1021/es404002c, 2014.

Jaffrezo, J. L., Davidson, C. I., Legrand, M., and Dibb, J. E.: Sulfate and MSA in the air and snow on the Greenland Ice Sheet, J. Geophys. Res., 99, 1241-1253, doi:10.1029/93JD02913, 1994.

Kahl, J. D. W., Martinez, D. A., Kuhns, H., Davidson, C. I., Jafferezo, J. L., and Harris, J. M.: Air mass trajectories to Summit, Greenland?: A 44-year climatology and some episodic events, J. Geophys. Res.-Ocean., 102, 26861-26875, 1997.

Kerkweg, A., Jöckel, P., Warwick, N., Gebhardt, S., Brenninkmeijer, C. A. M., and Lelieveld, J.: Consistent simulation of bromine chemistry from the marine boundary layer to the stratosphere - Part 2: Bromocarbons, Atmos. Chem. Phys., 8, 5919-5939, doi:10.5194/acp-8-5919-2008, 2008.

Kinnard, C., Zdanowicz, C. M., Koerner, R. M., and Fisher, D. A.: A changing Arctic seasonal ice zone: Observations from 18702003 and possible oceanographic consequences, Geophys. Res. Lett., 35, 2-6, doi:10.1029/2007GL032507, 2008.

Lamarque, J.-F., Dentener, F., McConnell, J., Ro, C.-U., Shaw, M., Vet, R., Bergmann, D., Cameron-Smith, P., Dalsoren, S., Doherty, R., Faluvegi, G., Ghan, S. J., Josse, B., Lee, Y. H., MacKenzie, I. A., Plummer, D., Shindell, D. T., Skeie, R. B., Stevenson, D. S., Strode, S., Zeng, G., Curran, M., Dahl-Jensen, D., Das, S., Fritzsche, D., and Nolan, M.: Multi-model mean nitrogen and sulfur deposition from the Atmospheric Chemistry and Climate Model Intercomparison Project (ACCMIP): evaluation of historical and projected future changes, Atmos. Chem. Phys., 13, 7997-8018, doi:10.5194/acp-13-7997-2013, 2013.

Langendörfer, U., Lehrer, E., Wagenbach, D., and Platt, U.: Observation of filterable bromine variabilities during Arctic tropospheric ozone depletion events in high (1 hour) time resolution, J. Atmos. Chem., 34, 39-54, doi:10.1023/A:1006217001008, 1999.

Legrand, M., Hammer, C., De Angelis, M., Savarino, J., Delmas, R., Clausen, H., and Johnsen, S. J.: Sulfur-containing species (methanesulfonate and $\mathrm{SO}_{4}$ ) over the last climatic cycle in the Greenland Ice Core Project (central Greenland) ice core, J. Geophys. Res., 102, 26663, doi:10.1029/97JC01436, 1997.

Lehrer, E., Wagenbach, D., and Platt, U.: Aerosol chemical composition during tropospheric ozone depletion at Ny Ålesund/Svalbard, Tellus B, 49, 1600-0889, doi:10.3402/tellusb.v49i5.15987, 1997.

Leu, E., Mundy, C. J., Assmy, P., Campbell, K., Gabrielsen, T. M., Gosselin, M., Juul-Pedersen, T., and Gradinger, R.: Arctic spring awakening - Steering principles behind the phenology of vernal ice algal blooms, Prog. Oceanogr., 139, 151-170, doi:10.1016/j.pocean.2015.07.012, 2015.
Li, S.-M. and Barrie, L. A.: Biogenic sulfur aerosol in the Arctic troposphere: 1. Contributions to total sulfate, J. Geophys. Res., 98, 20613, doi:10.1029/93JD02234, 1993.

Macias Fauria, M., Grinsted, A., Helama, S., Moore, J., Timonen, M., Martma, T., Isaksson, E., and Eronen, M.: Unprecedented low twentieth century winter sea ice extent in the Western Nordic Seas since A.D. 1200, Clim. Dynam., 34, 781-795, doi:10.1007/s00382-009-0610-z, 2010.

Mann, M. E., Bradley, R. S., and Hughes, M. K.: Global-scale temperature patterns and climate forcing over the past six centuries, Nature, 392, 779-787, doi:10.1038/33859, 1998.

Maselli, O. J., Fritzsche, D., Layman, L., McConnell, J. R., and Meyer, H.: Comparison of water isotope-ratio determinations using two cavity ring-down instruments and classical mass spectrometry in continuous ice-core analysis, Isotopes Environ. Health Stud., 49, 387-98, doi:10.1080/10256016.2013.781598, 2013.

McConnell, J.: Tunu, Greenland 2013 ice core chemistry, NSF Arctic Data Center, doi:10.18739/A2TM16, 2016.

McConnell, J. R. and Edwards, R.: Coal burning leaves toxic heavy metal legacy in the Arctic, P. Natl. Acad. Sci. USA, 105, 12140 12144, doi:10.1073/pnas.0803564105, 2008.

McConnell, J. R., Lamorey, G. W., Lambert, S. W., and Taylor, K. C.: Continuous ice-core chemical analyses using inductively coupled plasma mass spectrometry, Environ. Sci. Technol., 36, 7-11, doi:10.1021/es011088z, 2002.

McConnell, J. R., Edwards, R., Kok, G. L., Flanner, M. G., Zender, C. S., Saltzman, E. S., Banta, J. R., Pasteris, D. R., Carter, M. M., and Kahl, J. D. W.: 20th-Century Industrial Black Carbon Emissions Altered Arctic Climate Forcing, Science, 317, 13811384, doi:10.1126/science.1144856, 2007.

Millero, F. J.: The Physical Chemistry of Seawater, Annu. Rev. Earth Planet. Sc., 2, 101-150, doi:10.1146/annurev.ea.02.050174.000533, 1974.

Moldanová, J. and Ljungström, E.: Sea-salt aerosol chemistry in coastal areas: A model study, J. Geophys. Res., 106, 1271, doi:10.1029/2000JD900462, 2001.

Montzka, S. and Reimann, S.: Scientific Assessment of Ozone Depletion 2010: Scientific Summary Chapter 1 OzoneDepleting Substances (ODSs) and Related Chemicals, available at: http://www.esrl.noaa.gov/csd/assessments/ozone/2010/ summary/ch1.html (last access: 23 December 2015), 2010.

Morin, S., Savarino, J., Frey, M. M., Yan, N., Bekki, S., Bottenheim, J., and Martins, J. M. F.: Tracing the origin and fate of $\mathrm{NO}_{x}$ in the Arctic atmosphere using stable isotopes in nitrate, Science, 322, 730-732, doi:10.1126/science.1161910, 2008.

Mulvaney, R., Pasteur, E. C., Peel, D. A., Saltzman, E. S., and Whung, P.-Y.: The ratio of MSA to non-sea-salt sulphate in Antarctic Peninsula ice cores, Tellus B, 44, 1600-0889, doi:10.3402/tellusb.v44i4.15457, 1992.

Nghiem, S. V., Rigor, I. G., Richter, A., Burrows, J. P., Shepson, P. B., Bottenheim, J., Barber, D. G., Steffen, A., Latonas, J., Wang, F., Stern, G., Clemente-Colón, P., Martin, S., Hall, D. K., Kaleschke, L., Tackett, P., Neumann, G., and Asplin, M. G.: Field and satellite observations of the formation and distribution of Arctic atmospheric bromine above a rejuvenated sea ice cover, J. Geophys. Res.-Atmos., 117, D00S05, doi:10.1029/2011JD016268, 2012. 
Nriagu, J. O.: The rise and fall of leaded gasoline, Sci. Total Environ., 92, 13-28, 1990.

NSIDC (National Snow and Ice Data Center): available at: http: //nsidc.org/cryosphere/seaice/data/terminology.html, last access: December 2013.

O’Dwyer, J., Isaksson, E., Vinje, T., Jauhiainen, T., Moore, J., Pohjola, V., Vaikmae, R., and van de Wal, R. S. W.: Methanesulfonic acid in a Svalbard ice core as an indicator of ocean climate, Geophys. Res. Lett., 27, 1159-1162, doi:10.1029/1999GL011106, 2000.

Ordóñez, C., Lamarque, J.-F., Tilmes, S., Kinnison, D. E., Atlas, E. L., Blake, D. R., Sousa Santos, G., Brasseur, G., and Saiz-Lopez, A.: Bromine and iodine chemistry in a global chemistry-climate model: description and evaluation of very short-lived oceanic sources, Atmos. Chem. Phys., 12, 1423-1447, doi:10.5194/acp12-1423-2012, 2012.

Oudijk, G.: The Rise and Fall of Organometallic Additives in Automotive Gasoline, Environ. Forensics, 11, 17-49, doi:10.1080/15275920903346794, 2010.

Parrella, J. P., Jacob, D. J., Liang, Q., Zhang, Y., Mickley, L. J., Miller, B., Evans, M. J., Yang, X., Pyle, J. A., Theys, N., and Van Roozendael, M.: Tropospheric bromine chemistry: implications for present and pre-industrial ozone and mercury, Atmos. Chem. Phys., 12, 6723-6740, doi:10.5194/acp-12-6723-2012, 2012.

Pasteris, D. R., McConnell, J. R., and Edwards, R.: High-resolution, continuous method for measurement of acidity in ice cores, Environ. Sci. Technol., 46, 1659-1666, doi:10.1021/es202668n, 2012.

Pratt, K. A., Custard, K. D., Shepson, P. B., Douglas, T. A., Pöhler, D., General, S., Zielcke, J., Simpson, W. R., Platt, U., Tanner, D. J., Gregory Huey, L., Carlsen, M., and Stirm, B. H.: Photochemical production of molecular bromine in Arctic surface snowpacks, Nat. Geosci., 6, 351-356, doi:10.1038/ngeo1779, 2013.

Rankin, A. M., Wolff, E. W., and Martin, S.: Frost flowers: Implications for tropospheric chemistry and ice core interpretation, J. Geophys. Res.-Atmos., 107, 4683, doi:10.1029/2002JD002492, 2002.

Rayner, N. A.: Global analyses of sea surface temperature, sea ice, and night marine air temperature since the late nineteenth century, J. Geophys. Res., 108, 4407, doi:10.1029/2002JD002670, 2003.

Röthlisberger, R., Bigler, M., Hutterli, M., Sommer, S., Stauffer, B., Junghans, H. G., and Wagenbach, D.: Technique for continuous high-resolution analysis of trace substances in firn and ice cores, Environ. Sci. Technol., 34, 338-342, doi:10.1021/es9907055, 2000.

Röthlisberger, R., Mulvaney, R., Wolff, E. W., Hutterli, M. A., Bigler, M., Sommer, S., and Jouzel, J.: Dust and sea salt variability in central East Antarctica (Dome C) over the last $45 \mathrm{kyrs}$ and its implications for southern high-latitude climate, Geophys. Res. Lett., 29, 1-4, doi:10.1029/2003GL016936, 2002.

Saltzman, E. S., Dioumaeva, I., and Finley, B. D.: Glacial/interglacial variations in methanesulfonate (MSA) in the Siple Dome ice core, West Antarctica, Geophys. Res. Lett., 33, 1-4, doi:10.1029/2005GL025629, 2006.

Sander, R., Rudich, Y., von Glasow, R., and Crutzen, P. J.: The role of $\mathrm{BrNO}_{3}$ in marine tropospheric chemistry: A model study, Geophys. Res. Lett., 26, 2857-2860, doi:10.1029/1999GL900478, 1999.
Sander, R., Keene, W. C., Pszenny, A. A. P., Arimoto, R., Ayers, G. P., Baboukas, E., Cainey, J. M., Crutzen, P. J., Duce, R. A., Hönninger, G., Huebert, B. J., Maenhaut, W., Mihalopoulos, N., Turekian, V. C., and Van Dingenen, R.: Inorganic bromine in the marine boundary layer: a critical review, Atmos. Chem. Phys., 3, 1301-1336, doi:10.5194/acp-3-1301-2003, 2003.

Schönhardt, A., Begoin, M., Richter, A., Wittrock, F., Kaleschke, L., Gömez Martín, J. C., and Burrows, J. P.: Simultaneous satellite observations of $\mathrm{IO}$ and $\mathrm{BrO}$ over Antarctica, Atmos. Chem. Phys., 12, 6565-6580, doi:10.5194/acp-12-6565-2012, 2012.

Sharma, S., Chan, E., Ishizawa, M., Toom-Sauntry, D., Gong, S. L., Li, S. M., Tarasick, D. W., Leaitch, W. R., Norman, A., Quinn, P. K., Bates, T. S., Levasseur, M., Barrie, L. A., and Maenhaut, W.: Influence of transport and ocean ice extent on biogenic aerosol sulfur in the Arctic atmosphere, J. Geophys. Res.-Atmos., 117, D12209, doi:10.1029/2011JD017074, 2012.

Sigl, M., McConnell, J. R., Layman, L., Maselli, O. J., McGwire, K., Pasteris, D., Dahl-Jensen, D., Steffensen, J. P., Vinther, B., Edwards, R., Mulvaney, R., and Kipfstuhl, S.: A new bipolar ice core record of volcanism from WAIS Divide and NEEM and implications for climate forcing of the last 2000 years, J. Geophys. Res.-Atmos., 118, 1151-1169, doi:10.1029/2012JD018603, 2013.

Sigl, M., Winstrup, M., McConnell, J. R., Welten, K. C., Plunkett, G., Ludlow, F., Büntgen, U., Caffee, M., Chellman, N., Dahl-Jensen, D., Fischer, H., Kipfstuhl, S., Kostick, C., Maselli, O. J., Mekhaldi, F., Mulvaney, R., Muscheler, R., Pasteris, D. R., Pilcher, J. R., Salzer, M., Schüpbach, S., Steffensen, J. P., Vinther, B. M., and Woodruff, T. E.: Timing and climate forcing of volcanic eruptions for the past 2,500 years, Nature, 523, 543-9, doi:10.1038/nature14565, 2015.

Simpson, W. R., von Glasow, R., Riedel, K., Anderson, P., Ariya, P., Bottenheim, J., Burrows, J., Carpenter, L. J., Frieß, U., Goodsite, M. E., Heard, D., Hutterli, M., Jacobi, H.-W., Kaleschke, L., Neff, B., Plane, J., Platt, U., Richter, A., Roscoe, H., Sander, R., Shepson, P., Sodeau, J., Steffen, A., Wagner, T., and Wolff, E.: Halogens and their role in polar boundary-layer ozone depletion, Atmos. Chem. Phys., 7, 4375-4418, doi:10.5194/acp-74375-2007, 2007.

Sjostedt, S. J., Huey, L. G., Tanner, D. J., Peischl, J., Chen, G., Dibb, J. E., Lefer, B., Hutterli, M. A., Beyersdorf, A. J., Blake, N. J., Blake, D. R., Sueper, D., Ryerson, T., Burkhart, J., and Stohl, A.: Observations of hydroxyl and the sum of peroxy radicals at Summit, Greenland during summer 2003, Atmos. Environ., 41, 5122-5137, doi:10.1016/j.atmosenv.2006.06.065, 2007.

Smith, S. J., van Aardenne, J., Klimont, Z., Andres, R. J., Volke, A., and Delgado Arias, S.: Anthropogenic sulfur dioxide emissions: 1850-2005, Atmos. Chem. Phys., 11, 1101-1116, doi:10.5194/acp-11-1101-2011, 2011.

Spolaor, A., Vallelonga, P., Plane, J. M. C., Kehrwald, N., Gabrieli, J., Varin, C., Turetta, C., Cozzi, G., Kumar, R., Boutron, C., and Barbante, C.: Halogen species record Antarctic sea ice extent over glacial-interglacial periods, Atmos. Chem. Phys., 13, 66236635, doi:10.5194/acp-13-6623-2013, 2013a.

Spolaor, A., Gabrieli, J., Martma, T., Kohler, J., Björkman, M. B., Isaksson, E., Varin, C., Vallelonga, P., Plane, J. M. C., and Barbante, C.: Sea ice dynamics influence halogen deposition to Svalbard, The Cryosphere, 7, 1645-1658, doi:10.5194/tc-71645-2013, 2013b. 
Spolaor, A., Vallelonga, P., Gabrieli, J., Martma, T., Björkman, M. P., Isaksson, E., Cozzi, G., Turetta, C., Kjær, H. A., Curran, M. A. J., Moy, A. D., Schönhardt, A., Blechschmidt, A.-M., Burrows, J. P., Plane, J. M. C., and Barbante, C.: Seasonality of halogen deposition in polar snow and ice, Atmos. Chem. Phys., 14, 96139622, doi:10.5194/acp-14-9613-2014, 2014.

Spolaor, A., Opel, T., McConnell, J. R., Maselli, O. J., Spreen, G., Varin, C., Kirchgeorg, T., Fritzsche, D., Saiz-Lopez, A., and Vallelonga, P.: Halogen-based reconstruction of Russian Arctic sea ice area from the Akademii Nauk ice core (Severnaya Zemlya), The Cryosphere, 10, 245-256, doi:10.5194/tc-10-2452016, 2016.

Sturges, W. T. and Harrison, R. M.: Bromine: Lead ratios in airborne particles from urban and rural sites, Atmos. Environ., 20, 577588, doi:10.1016/0004-6981(86)90101-0, 1986.

Thomas, J. L., Dibb, J. E., Huey, L. G., Liao, J., Tanner, D., Lefer, B., von Glasow, R., and Stutz, J.: Modeling chemistry in and above snow at Summit, Greenland - Part 2: Impact of snowpack chemistry on the oxidation capacity of the boundary layer, Atmos. Chem. Phys., 12, 6537-6554, doi:10.5194/acp-12-65372012, 2012.

Thomas, V. M., Bedford, J. A., and Cicerone, R. J.: Bromine emissions from leaded gasoline, Geophys. Res. Lett., 24, 1371-1374, doi:10.1029/97GL01243, 1997.

Vestreng, V., Ntziachristos, L., Semb, A., Reis, S., Isaksen, I. S. A., and Tarrasón, L.: Evolution of $\mathrm{NO}_{x}$ emissions in Europe with focus on road transport control measures, Atmos. Chem. Phys., 9, 1503-1520, doi:10.5194/acp-9-1503-2009, 2009.

Wagner, T., Leue, C., Wenig, M., Pfeilsticker, K., and Platt, U.: Spatial and temporal distribution of enhanced boundary layer $\mathrm{BrO}$ concentrations measured by the GOME instrument aboard ERS2, J. Geophys. Res., 106, 24225, doi:10.1029/2000JD000201, 2001.

WAIS Divide Project Members: Onset of deglacial warming in West Antarctica driven by local orbital forcing, Nature, 500, 440-444, doi:10.1038/nature12376, 2013.
Walsh, J. E.: A data set on Northern Hemisphere sea ice extent, Glaciological Data, Report GD-2, Part 1, National Snow and Ice Data Center, 49-51, 1978.

Weißbach, S., Wegner, A., Opel, T., Oerter, H., Vinther, B. M., and Kipfstuhl, S.: Spatial and temporal oxygen isotope variability in northern Greenland - implications for a new climate record over the past millennium, Clim. Past, 12, 171-188, doi:10.5194/cp12-171-2016, 2016.

Weller, R.: Postdepositional losses of methane sulfonate, nitrate, and chloride at the European Project for Ice Coring in Antarctica deep-drilling site in Dronning Maud Land, Antarctica, J. Geophys. Res., 109, 1-9, doi:10.1029/2003JD004189, 2004.

WMO: Scientific Assessment of Ozone Depletion: 1994, Chapter 10: Methyl Bromide, Geneva, 1995.

WMO: Scientific Assessment of Ozone Depletion: 2002, Chapter 1: Controlled Substances and Other Source Gases, Geneva, 2003.

Wolff, E. W.: Ice sheets and nitrogen, Philos. T. R. Soc. Lond. B, 368, 20130127, doi:10.1098/rstb.2013.0127, 2013.

Wolff, E. W., Rankin, A. M., and Röthlisberger, R.: An ice core indicator of Antarctic sea ice production?, Geophys. Res. Lett., 30, 2-5, doi:10.1029/2003GL018454, 2003.

Xu, L., Russell, L. M., Somerville, R. C. J., and Quinn, P. K.: Frost flower aerosol effects on Arctic wintertime longwave cloud radiative forcing, J. Geophys. Res.-Atmos., 118, 13282-13291, doi:10.1002/2013JD020554, 2013.

Yang, X., Pyle, J. A., and Cox, R. A.: Sea salt aerosol production and bromine release: Role of snow on sea ice, Geophys. Res. Lett., 35, 1-5, doi:10.1029/2008GL034536, 2008.

Yang, X., Pyle, J. A., Cox, R. A., Theys, N., and Van Roozendael, M.: Snow-sourced bromine and its implications for polar tropospheric ozone, Atmos. Chem. Phys., 10, 7763-7773, doi:10.5194/acp-10-7763-2010, 2010.

Yung, Y. L., Pinto, J. P., Watson, R. T., and Sander, S. P.: Atmospheric Bromine and Ozone Perturbations in the Lower Stratosphere, J. Atmos. Sci., 37, 339-353, doi:10.1175/15200469(1980)037<0339:ABAOPI>2.0.CO;2, 1980. 